\title{
The influence of ${ }^{14} \mathrm{C}$ reservoir age on interpretation of paleolimnological records from the Tibetan Plateau
}

\author{
Juzhi Hou $^{\mathrm{a}, *}$, William J. D’Andrea ${ }^{\mathrm{b}}$, Zhonghui Liu ${ }^{\mathrm{c}}$ \\ ${ }^{a}$ Key Laboratory of Tibetan Environment Changes and Land Surface Processes, Institute of Tibetan Plateau Research, Chinese Academy of Sciences, Beijing 100085, China \\ ${ }^{\mathrm{b}}$ Lamont Doherty Earth Observatory, Columbia University, Palisades, NY 10964, USA \\ ${ }^{\mathrm{c}}$ Department of Earth Sciences, The University of Hong Kong, Hong Kong, China
}

\section{A R T I C L E I N F O}

Article history:

Received 14 April 2011

Received in revised form 10 June 2012

Accepted 15 June 2012

Available online $\mathrm{xxx}$

\section{Keywords:}

Tibetan Plateau

Lake

Reservoir age

Radiocarbon chronology

Climate change

Paleoclimate

\begin{abstract}
A B S T R A C T
There is a great deal of controversy regarding the fate of glaciers and ice fields on the Tibetan Plateau in the face of continued anthropogenic global warming. Paleoclimate reconstructions and spatial analyses aimed at mapping past climate changes are the key to understanding the climatic response of the Tibetan Plateau to changing conditions. Specifically, the numerous lakes distributed across the Tibetan Plateau can provide high-resolution (spatial and temporal) climate reconstructions to investigate past changes in the climate system. In this paper, we review the primary limitation to exploiting these valuable paleoclimate archives: errors in radiocarbon-based age models. We review the techniques that have been used to estimate ${ }^{14} \mathrm{C}$ reservoir ages on the Tibetan Plateau and compile the published ${ }^{14} \mathrm{C}$ reservoir ages to examine their spatial and temporal patterns and to assess the imposed chronological uncertainties. Using site-specific evaluations of Bangong Co and Lake Qinghai, we demonstrate that ${ }^{14} \mathrm{C}$ age model uncertainties permit equally probable and contrasting interpretations of existing paleoclimate records. We also examine ${ }^{14} \mathrm{C}$-induced uncertainties in the spatial climatic response on the Tibetan Plateau to (1) the termination of the Last Glacial Maximum and (2) the Holocene Thermal Maximum. We conclude with recommendations for reducing uncertainties in future lake-based paleoclimate studies on the Tibetan Plateau.
\end{abstract}

(c) 2012 Elsevier Ltd. All rights reserved.

\section{Introduction}

\subsection{Climate of the Tibetan Plateau}

The Tibetan Plateau (TP) is the largest and highest plateau on Earth, often referred to as the Third Pole (Qiu, 2008), and hosts the third largest continental ice reservoir after Antarctica and Greenland. Glaciers of the TP provide water to most Asian river systems and provide water for over 1.5 billion people, more than $20 \%$ of the world population (Barnett et al., 2005). However, the glaciers are retreating rapidly as a result of global warming (Kehrwald et al., 2008). Effective water resource planning will rely on projections of future climate change on the TP. Within this framework, there has been renewed interest in understanding the complex climate dynamics of the TP.

\footnotetext{
* Corresponding author. Institute of Tibetan Plateau Research, Chinese Academy of Sciences, 4A Datun Road, Chaoyang, Beijing 100101, China. Tel.: +86 108409 7077; fax: +86108409 7079 .

E-mail address: houjz@itpcas.ac.cn (J. Hou).
}

The climate of the TP is influenced by the East Asian monsoon, the Indian monsoon, and the mid-latitude Westerlies (Fig. 1) (An et al., 2000, 2001; Vandenberghe et al., 2006; Chen et al., 2008). In summer, the pressure gradient between the Asian continent and the oceans drives low altitude moist airflow inland and brings rainfall to the eastern and southern TP. The degree to which the westerly winds of the Atlantic climate system penetrate the Asian landmass depends upon the relative strength of the westerlies and the Asian monsoonal systems, which in turn is controlled by the air pressure gradients over the North Atlantic and the Siberian highpressure cell (Vandenberghe et al., 2006; Thompson et al., 2006a; Chen et al., 2008). Variations in these large physical systems result in very complex climatology over the TP.

To examine how TP climatology varies under different climatic regimes requires a longer-term perspective than is provided by instrumental records. There have been numerous efforts to reconstruct past climate variability across the TP with a variety of paleoclimate archives. For example, tree ring records in the northeastern TP (Sheppard et al., 2004; Shao et al., 2007, 2009) and southeastern TP (Liang et al., 2009) offer detailed information regarding the climate of the past millennia and a few extend longer 


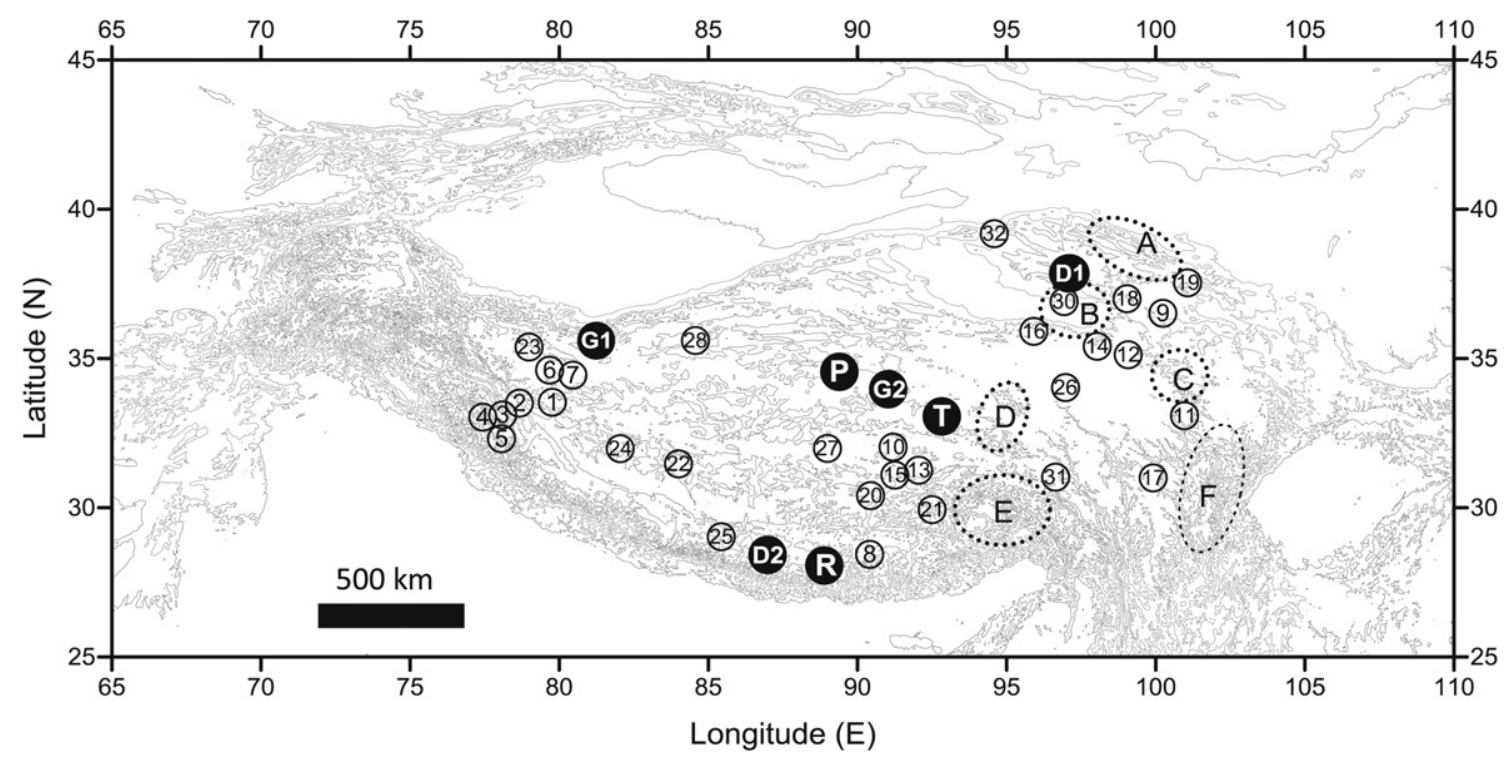

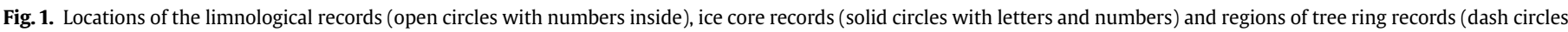

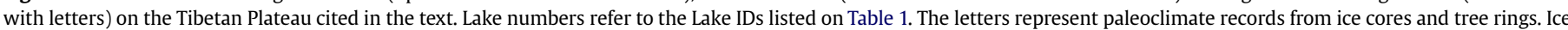

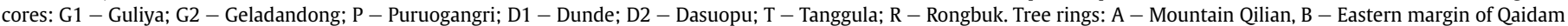
Basin, C - Mountain Amne Machin, D - Source region of three rivers, E - Southeastern Tibetan Plateau, F - Western Sichuan.

than 3000 years (Shao et al., 2009). Ice cores from high elevation mountains contain records of past climate variability spanning hundreds of thousands of years (Yao et al., 1992; Yao et al., 1996; Thompson et al., 1997, 2006a, 2006b; Yao et al., 1997; Yao, 1999; Thompson et al., 2000; Wang et al., 2003; Yao et al., 2006). Lake sediment cores have provided paleoclimate reconstructions extending back as far as the Last Glacial Maximum (References cited in this paper).

Different mechanisms have been proposed to explain the patterns of climate change evident in paleoclimate reconstructions during the Holocene. Based on ice core studies, Thompson et al. (2006a) proposed that the southern, eastern and central sectors of the TP were mainly influenced by the East Asian monsoon and Indian monsoon during the Holocene, while the northeastern regions were alternatively influenced by the monsoon system in summer and the westerlies in winter (Thompson et al., 2006a). An et al. (2000) argued that changes in insolation-induced monsoon strength (East Asian and Indian Monsoon systems) were responsible for the step-wise relocation of maximal precipitation from north to south China during the Holocene (An et al., 2000). Chen et al. (2008), based on paleolimnological records, suggested that climate dynamics in arid western China, where climate records show significant anti-phase correlation with records in monsoondominated regions (including most parts of TP) during the Holocene, have been mainly controlled by the westerlies (Chen et al., 2008). Chen et al. (2008) and He et al. (2004) proposed that the monsoons and the westerlies dominated climate on the central TP at different periods during the Holocene (He et al., 2004; Chen et al., 2008). Although all of these proposed climate histories are based on the premise of varying relative strength of the westerlies and monsoon systems, the spatial and temporal variations are difficult to resolve in the absence of a dense network of quantitative paleoclimate records.

Limnological records of climate variability provide the best opportunity constructing dense networks of paleoclimate records on the TP. Tree ring and ice core records are geographically limited to the northeastern and southeastern plateau margin, where trees can survive, and to the high elevation mountains where ice can accumulate continuously (Fig. 1). Speleothem $\delta^{18} \mathrm{O}$ records have been reported in one case in south-central TP (Cai et al., 2010). In contrast, there are over 1000 lakes distributed across the TP that can provide quantitative climate reconstructions for deciphering spatial and temporal patterns of past climate change.

\subsection{Lakes of the Tibetan Plateau}

There are 1091 lakes larger than $1 \mathrm{~km}^{2}$ and 346 lakes larger than $10 \mathrm{~km}^{2}$ on the TP (Wang and Dou, 1998; Ma et al., 2011). The first documented lake investigations by early geographers and explorers were in the 1840s (Strachey, 1853). In recent decades, sediment cores from dozens of lakes have been investigated using various paleoclimate approaches (Fig. 1 and Table 1). Many lakes have yielded apparently high quality paleoclimate records from the TP, yet there is still disagreement and uncertainty concerning the spatial and temporal patterns of past climate changes, and the associated forcing mechanisms.

Uncertainties in the age models used to convert sediment depth to age represent a major limitation of existing paleolimnological records from the TP. Most age models have been developed using radiocarbon $\left({ }^{14} \mathrm{C}\right)$ dating of various organic and inorganic components within lake sediment, and even under ideal conditions the ${ }^{14} \mathrm{C}$ dating method has associated uncertainties (for a discussion of these uncertainties, see (Scott, 2007)). Various forms of organic matter can be ${ }^{14} \mathrm{C}$ dated, including material from allochthonous (terrestrial plants) and autochthonous (algae, bacteria and macrophytes in the lake) sources. While the former derive carbon from atmospheric $\mathrm{CO}_{2}$, the latter derive carbon, directly or indirectly, from dissolved inorganic carbon (DIC) in lake water (Meyers, 2003). The carbon isotopic composition of DIC in lake water depends on a number of factors, including equilibration with atmospheric $\mathrm{CO}_{2}$, decomposition and remineralization of organic matter, and the rate of carbonate weathering and dissolution (Hatte and Jull, 2007). Carbonate bedrock contributes ${ }^{14} \mathrm{C}$-dead DIC to lakes and results in erroneously old ${ }^{14} \mathrm{C}$ ages for lake water. Undifferentiated sedimentary organic carbon (bulk carbon) in lakes contains a mixture of allochthonous and autochthonous carbon and therefore requires a correction for contributions from ${ }^{14} \mathrm{C}$-dead or ${ }^{14} \mathrm{C}$-depleted sources. Therefore, it is critical to determine reservoir ages for TP lakes 
Table 1

The location of the lake records cited in this paper.

\begin{tabular}{|c|c|c|c|c|c|}
\hline No. & Name & Other names & Longitude & Latitude & Alt (m) \\
\hline 1 & Bangong Co & Pangong Tso & $79^{\circ} 49^{\prime} 27.98^{\prime \prime} \mathrm{E}$ & $33^{\circ} 31^{\prime} 29.74^{\prime \prime} \mathrm{N}$ & 4238 \\
\hline 2 & Tso Pongur & Mandong Co & $78^{\circ} 58^{\prime} 11.30^{\prime \prime} \mathrm{E}$ & $33^{\circ} 31^{\prime} 31.31^{\prime \prime} \mathrm{N}$ & 4295 \\
\hline 3 & Mirpa Tso & Mirpal Tso & $78^{\circ} 36^{\prime} 37.89^{\prime \prime} \mathrm{E}$ & $33^{\circ} 27^{\prime} 50.37^{\prime \prime} \mathrm{N}$ & 4919 \\
\hline 4 & Tso Morari & Tso Moriri & $78^{\circ} 18^{\prime} 57.63^{\prime \prime} \mathrm{E}$ & $32^{\circ} 53^{\prime} 13.50^{\prime \prime} \mathrm{N}$ & 4527 \\
\hline 5 & Tso Kar & & $78^{\circ} 02^{\prime} 43.11^{\prime \prime} \mathrm{E}$ & $33^{\circ} 14^{\prime} 57.72^{\prime \prime} \mathrm{N}$ & 4537 \\
\hline 6 & Sumxi Co & Songmuxi Co & $80^{\circ} 14^{\prime} 25.99^{\prime \prime} \mathrm{E}$ & $34^{\circ} 36^{\prime} 13.75^{\prime \prime} \mathrm{N}$ & 5051 \\
\hline 7 & Longmu Co & Co Longna & $80^{\circ} 29^{\prime} 29.69^{\prime \prime} \mathrm{E}$ & $34^{\circ} 36^{\prime} 18.53^{\prime \prime} \mathrm{N}$ & 5003 \\
\hline 8 & Pum Yumco & Pumoyong Tso & $90^{\circ} 21^{\prime} 02.95^{\prime \prime} \mathrm{E}$ & $28^{\circ} 33^{\prime} 23.76^{\prime \prime} \mathrm{N}$ & 5080 \\
\hline 9 & Lake Qinghai & & $100^{\circ} 10^{\prime} 10.00^{\prime \prime} \mathrm{E}$ & $36^{\circ} 52^{\prime} 03.00^{\prime \prime} \mathrm{N}$ & 3193 \\
\hline 10 & Zigê Tangco & Zigê Danco & $90^{\circ} 53^{\prime} 30.00^{\prime \prime} \mathrm{E}$ & $32^{\circ} 04^{\prime} 22.00^{\prime \prime} \mathrm{N}$ & 4567 \\
\hline 11 & Ximen Co & & $101^{\circ} 05^{\prime} 60.00^{\prime \prime} \mathrm{E}$ & $33^{\circ} 22^{\prime} 48.00^{\prime \prime} \mathrm{N}$ & 4010 \\
\hline 12 & Lake Kuhai & Dou Co & $99^{\circ} 10^{\prime} 56.83^{\prime \prime} \mathrm{E}$ & $35^{\circ} 18^{\prime} 00.03^{\prime \prime} \mathrm{N}$ & 4126 \\
\hline 13 & Ahung Co & & $92^{\circ} 03^{\prime} 49.69^{\prime \prime} \mathrm{E}$ & $31^{\circ} 37^{\prime} 12.96^{\prime \prime} \mathrm{N}$ & 4560 \\
\hline 14 & Donggi Cona & Lake Tuosu & $98^{\circ} 31^{\prime} 60.00^{\prime \prime} \mathrm{E}$ & $35^{\circ} 17^{\prime} 60.00^{\prime \prime} \mathrm{N}$ & 4200 \\
\hline 15 & Co Ngoin & Co E & $91^{\circ} 29^{\prime} 45.00^{\prime \prime} \mathrm{E}$ & $31^{\circ} 27^{\prime} 01.00^{\prime \prime} \mathrm{N}$ & 4522 \\
\hline 16 & Lake Kusai & Lake Hoh Sai & $92^{\circ} 53^{\prime} 56.66^{\prime \prime} \mathrm{E}$ & $35^{\circ} 43^{\prime} 26.22^{\prime \prime} \mathrm{N}$ & 4475 \\
\hline 17 & Lake Naleng & & $99^{\circ} 45^{\prime} 16.22^{\prime \prime} \mathrm{E}$ & $31^{\circ} 6^{\prime} 32.10^{\prime \prime} \mathrm{N}$ & 4194 \\
\hline 18 & Caka Salt Lake & & $99^{\circ} 06^{\prime} 23.16^{\prime \prime} \mathrm{E}$ & $36^{\circ} 41^{\prime} 33.87^{\prime \prime} \mathrm{N}$ & 3060 \\
\hline 19 & Lake Luanhaizi & Lake Eye & $101^{\circ} 20^{\prime} 41.40^{\prime \prime} \mathrm{E}$ & $37^{\circ} 35^{\prime} 43.56^{\prime \prime} \mathrm{N}$ & 3197 \\
\hline 20 & Nam Co & & $90^{\circ} 29^{\prime} 29.69^{\prime \prime} \mathrm{E}$ & $30^{\circ} 40^{\prime} 59.29^{\prime \prime} \mathrm{N}$ & 4724 \\
\hline 21 & Hidden Lake & Haideng Lake & $92^{\circ} 23^{\prime} 20.51^{\prime \prime} \mathrm{E}$ & $29^{\circ} 46^{\prime} 43.49^{\prime \prime} \mathrm{N}$ & 4916 \\
\hline 22 & Chabyer Caka & Zhabuye Caka & $84^{\circ} 03^{\prime} 46.47^{\prime \prime} \mathrm{E}$ & $31^{\circ} 23^{\prime} 46.03^{\prime \prime} \mathrm{N}$ & 4424 \\
\hline 23 & Lake Hongshan & & $78^{\circ} 56^{\prime} 11.21^{\prime \prime} \mathrm{E}$ & $35^{\circ} 27^{\prime} 42.02^{\prime \prime} \mathrm{N}$ & 4834 \\
\hline 24 & Nyer Co & Nie'Er Co & $82^{\circ} 13^{\prime} 30.00^{\prime \prime} \mathrm{E}$ & $32^{\circ} 15^{\prime} 60.00^{\prime \prime} \mathrm{N}$ & 4399 \\
\hline 25 & Peiku Co & Paiku Co & $85^{\circ} 37^{\prime} 02.90^{\prime \prime} \mathrm{E}$ & $28^{\circ} 51^{\prime} 21.99^{\prime \prime} \mathrm{N}$ & 4580 \\
\hline 26 & Lake Koucha & Lake Kucha & $97^{\circ} 13^{\prime} 49.56^{\prime \prime} \mathrm{E}$ & $34^{\circ} 00^{\prime} 32.04^{\prime \prime} \mathrm{N}$ & 4531 \\
\hline 27 & Serling Co & Selin Co & $89^{\circ} 04^{\prime} 47.05^{\prime \prime} \mathrm{E}$ & $31^{\circ} 46^{\prime} 31.69^{\prime \prime} \mathrm{N}$ & 4538 \\
\hline 28 & Lake Yang & & $84^{\circ} 37^{\prime} 52.14^{\prime \prime} \mathrm{E}$ & $35^{\circ} 25^{\prime} 25.95^{\prime \prime} \mathrm{N}$ & 4783 \\
\hline 29 & $\mathrm{Co} \mathrm{Ne}$ & & $87^{\circ} 14^{\prime} 27.13^{\prime \prime} \mathrm{E}$ & $34^{\circ} 41^{\prime} 27.94^{\prime \prime} \mathrm{N}$ & 4909 \\
\hline 30 & Lake Hurleg & Lake Keluke & $96^{\circ} 53^{\prime} 31.72^{\prime \prime} \mathrm{E}$ & $37^{\circ} 16^{\prime} 59.02^{\prime \prime} \mathrm{N}$ & 2814 \\
\hline 31 & Ren Co & & $96^{\circ} 40^{\prime} 15.06^{\prime \prime} \mathrm{E}$ & $30^{\circ} 42^{\prime} 31.01^{\prime \prime} \mathrm{N}$ & 4442 \\
\hline 32 & Lake Sugan & & $93^{\circ} 49^{\prime} 09.66^{\prime \prime} \mathrm{E}$ & $38^{\circ} 51^{\prime} 34.99^{\prime \prime} \mathrm{N}$ & 2796 \\
\hline
\end{tabular}

as part of any paleolimnologic study that requires accurate chronological control.

This fact is widely known, and most researchers have considered the influence of the ${ }^{14} \mathrm{C}$ reservoir effect when developing age models for lake sediment cores. For example, Yang and Scuderi (2010) and Yang et al. (2010, 2011) obtained modern reservoir ages on organic and inorganic carbon from lakes between desert dunes northeast of the TP (Yang and Scuderi, 2010; Yang et al., 2010, 2011). However, published calculations of reservoir ages differ significantly depending on the techniques used for determination and, in some cases, even between studies that have used the same approach in a single lake. For example, in Lake Qinghai, Shen et al. (2005) used linear extrapolation from ten ${ }^{14} \mathrm{C}$ measurements on bulk organic carbon to calculate a reservoir age of $1039 \mathrm{yr}$ for the entire Holocene and Zhang et al. (1994) arrived at a similar value of 1100 years. However, using the same technique, the reservoir age was determined to be $658 \mathrm{yr}$ by Henderson et al. (2010). Using a geochemical model, Yu et al. (2007) estimated a reservoir age of $1500 \mathrm{yr}$ for Lake Qinghai. The discrepancy in reservoir ages from these studies results in chronological uncertainty of about 1000 years, severely limiting the utility of climate interpretations derived from these sediment cores.

Due to the large chronological uncertainties, observed spatial patterns of climate change through time cannot be distinguished from age model artifacts. In this paper, we 1) review the techniques used to estimate reservoir ages in lake sediment cores on the TP and evaluate the chronological uncertainties imposed by various techniques; 2 ) compile the published lake reservoir ages on the TP to examine their spatial and temporal patterns; 3 ) re-visit the paleolimnological records at Bangong Co and Lake Qinghai to assess the influence of chronological uncertainty on paleoclimate interpretation; and 4) examine the impact of chronological uncertainty on dating the termination of the Last Glacial Maximum and the timing and evolution of the Holocene Thermal Maximum (HTM) on the TP.

\section{Paleolimnologic studies on the Tibetan Plateau}

A geographical representation of the published paleolimnologic studies considered in this review is shown in Fig. 1 (see online KML (GoogleMaps) files). The studies are biased towards eastern Qinghai Province, southeastern, southern and western Tibet reflecting ease of site accessibility. There have only been two lake studies, Co Ne and Lake Yang, reported from northern Tibet and western Qinghai Province (Zhao et al., 2007b), although this region represents the largest national reserve in China and hosts hundreds of lakes. There are hundreds of published proxy-based paleoclimate records and dozens of reservoir age estimates from the lakes on the TP. Here, we review only those studies that span the past 20,000 years and report reservoir ages and dating methods. ${ }^{14} \mathrm{C}$ ages reported in the original studies were calibrated using CALIB 6.0 (Stuiver et al., 2011). Table 1 lists the lakes that met our review criteria.

For historical reasons, and due to the variety of languages used in Tibet, individual lakes may have several names, and different names have been used for the same lake in different publications. This will certainly cause confusion for researchers intending to synthesize and compare paleolimnological data from the TP. In this review, we adopted the names listed in the Map of Glaciers and Lakes on the Qinghai-Xizang (Tibet) Plateau and Adjoining Regions (Yao, 2008) and the monograph of Lakes in China (Wang and Dou, 1998).

\section{3. ${ }^{14} \mathrm{C}$ reservoir ages for lakes of the Tibetan Plateau}

\subsection{Modern calibration approach}

One approach for estimating the reservoir age of a lake involves determining the ${ }^{14} \mathrm{C}$ age of a modern component of the lake system. The modern component may be 1 ) bulk organic matter in surface sediment or a component thereof (e.g., the humin or humic fraction), 2) dissolved inorganic carbon (DIC) and dissolved organic 
carbon (DOC) in lake water, 3) living aquatic plants, or 4) authigenic carbonate in surface sediment. The ${ }^{14} \mathrm{C}$ age of this modern component, if older than the expected age of zero, represents the modern ${ }^{14} \mathrm{C}$ reservoir age of the lake. This approach to estimating the ${ }^{14} \mathrm{C}$ reservoir age has associated limitations and uncertainties. Different modern components of a given lake can have different ${ }^{14} \mathrm{C}$ reservoir ages due to differences in relative contributions from various carbon sources. For example, in Lake Donggi Cona the ${ }^{14} \mathrm{C}$ reservoir corrections determined from humin, humic acids and bulk organic carbon in the lake surface sediment are 1983, 1655, and 1947 years, respectively (Table 2) (Mischke et al., 2010). Furthermore, lake water at different locations within a given lake may have different ${ }^{14} \mathrm{C}$ activity due to proximity to river input. For example, lake water DIC in the eastern basin of Bangong Co shows a smaller ${ }^{14} \mathrm{C}$ reservoir age (ca $3200{ }^{14} \mathrm{C}$ years) than water from northern margin (ca $5700{ }^{14} \mathrm{C}$ years) due to differences in carbonate dissolution and river input (Fontes et al., 1996). The choice of the carbon pool used to represent modern values, therefore, can have a significant impact on the estimated reservoir ages (Table 2). Moreover, the calibration of modern reservoir should be very careful due to the presence of the Suess effect (Keeling, 1979; Tans et al., 1979). The ${ }^{14} \mathrm{C}$ content in the modern atmosphere has been changed significantly by the admixture of large amounts of fossil fuel derived $\mathrm{CO}_{2}$, which further complicates the calculation of modern reservoir ages in a lake.

\subsection{Linear extrapolation of ${ }^{14} \mathrm{C}$ dates}

Another approach to estimate the modern ${ }^{14} \mathrm{C}$ reservoir age involves linearly extrapolating the downcore ${ }^{14} \mathrm{C}$ age-depth relationship to the sediment-water interface and defining the modern reservoir age as the extrapolated ${ }^{14} \mathrm{C}$ age at the sediment surface. Modern ${ }^{14} \mathrm{C}$ reservoir ages at Co Ngoin (Wu et al., 2006, 2010), Lake Qinghai (Shen et al., 2005; Henderson and Holmes, 2009; Henderson et al., 2010), Bangong Co (Fontes et al., 1996), Lake Kusai (Wang et al., 2008), Lake Naleng (Kramer et al., 2009, 2010) were obtained using this technique (Table 2). An assumption made when applying this approach is that sedimentation rates have remained constant throughout the sediment core, which is unlikely for most lakes. If the sedimentation rate in a lake has changed through time, extrapolation of the ${ }^{14} \mathrm{C}$-based age model cannot accurately represent the modern ${ }^{14} \mathrm{C}$ reservoir age. Indeed, reservoir age

Table 2

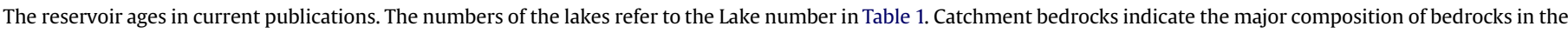

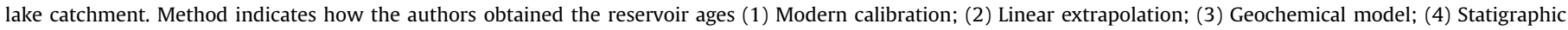
alignment; and (5) Independent age determination.

\begin{tabular}{|c|c|c|c|c|c|c|}
\hline No. & Lake & Catchment bedrock & RA & Method & $\begin{array}{l}\text { Materials for }{ }^{14} \mathrm{C} \\
\text { measurements }\end{array}$ & Reference \\
\hline 1 & Bangong Co & Limestone, schist & 6670 & (2) & $\begin{array}{l}\text { Authigenic inorganic } \\
\text { carbonate }\end{array}$ & (Fontes et al., 1996) \\
\hline 5 & Tso Kar & Limestone & 2035 & (5) & Total organic carbon & (Demske et al., 2009) \\
\hline 6 & Sumxi Co & $\begin{array}{l}\text { Schist, sandstone, } \\
\text { carbonate }\end{array}$ & 2100 & (1) & Aquatic plants, ostracod & (Fontes et al., 1993) \\
\hline 7 & Longmu Co & $\begin{array}{l}\text { Schists, sandstone, } \\
\text { carbonate }\end{array}$ & 4400 & (1) & Aquatic plants, ostracod & (Fontes et al., 1993) \\
\hline \multirow[t]{10}{*}{9} & \multirow[t]{10}{*}{ Lake Qinghai } & \multirow{10}{*}{$\begin{array}{l}\text { Limestone, sandstone, } \\
\text { shale }\end{array}$} & 1100 & (2) & Total organic carbon & (Kelts et al., 1989) \\
\hline & & & 439 & (2) & Total organic carbon & (Zhang et al., 1994) \\
\hline & & & 1039 & (2) & Total organic carbon & (Ji et al., 2005) \\
\hline & & & 1039 & (2) & Total organic carbon & (Shen et al., 2005) \\
\hline & & & 1039 & (2) & Total organic carbon & (Liu et al., 2006) \\
\hline & & & 1500 & (3) & - & (Yu et al., 2007) \\
\hline & & & $1549(800-1650)$ & (3) & - & (Wang et al., 2007) \\
\hline & & & 1166 & (1) & Total organic carbon & (Ji et al., 2009) \\
\hline & & & 658 & (1) & Authigenic carbonate & (Henderson et al., 2010) \\
\hline & & & 737 & (2) & Total organic carbon & (Henderson et al., 2010) \\
\hline \multirow[t]{3}{*}{10} & \multirow[t]{3}{*}{ Zigê Tangco } & \multirow[t]{3}{*}{ Sandstone, limestone, } & 2000 & (1) & Total organic carbon & (Herzschuh et al., 2006b) \\
\hline & & & 2010 & (1) & Total organic carbon & (Shen et al., 2007) \\
\hline & & & 2060 & (5) & Total organic carbon & (Wu et al., 2007) \\
\hline 11 & Ximen Co & Schist & 869 & (1) & $\begin{array}{l}\text { Alkali insoluble organic } \\
\text { matter }\end{array}$ & $\begin{array}{l}\text { (Zhang and Mischke, 2009; } \\
\text { Mischke and Zhang, 2010) }\end{array}$ \\
\hline \multirow[t]{2}{*}{12} & \multirow[t]{2}{*}{ Lake Kuhai } & \multirow[t]{2}{*}{ Sandstone, shale } & 867 & (1) & Alkali soluble organic matter & (Mischke et al., 2009) \\
\hline & & & 2333 & (1) & Alkali insoluble organic & \\
\hline 13 & Ahung Co & Quartzite, shale dolomite & 650 & (1) & Aquatic plants & (Morrill et al., 2006) \\
\hline \multirow[t]{3}{*}{14} & \multirow[t]{3}{*}{ Donggi Cona } & \multirow[t]{3}{*}{ Limestone, clastic rocks } & 1983 & (1) & Total organic carbon & (Mischke et al., 2010) \\
\hline & & & 1655 & (1) & Humic fraction in sediment & \\
\hline & & & 1947 & (1) & Humin fraction in sediment & \\
\hline \multirow[t]{2}{*}{15} & \multirow[t]{2}{*}{ Co Ngion } & \multirow[t]{2}{*}{ Sandstone, granite } & 3470 & (2) & total organic carbon & $\begin{array}{l}\text { (Wu et al., 2006; Wu } \\
\text { et al., 2010) }\end{array}$ \\
\hline & & & 2000 & (1) & Aquatic plants & (Tang et al., 2009) \\
\hline 16 & Lake Kusai & Shale & 3400 & (2) & Total organic carbon & $\begin{array}{l}\text { (Wang et al., 2008; Liu } \\
\text { et al., 2009) }\end{array}$ \\
\hline 17 & Lake Naleng & Glacial sill & 1560 & (2) & Total organic carbon & (Kramer et al., 2009, 2010) \\
\hline 18 & Caka Salt Lake & Fluvial & 1700 & (4) & - & (Liu et al., 2008) \\
\hline 19 & Lake Luanhaizi & & 720 & (5) & Ostracod, aquatic plants & (Mischke et al., 2005) \\
\hline 20 & Nam Co & Clastic rocks limestone & $2476(1200-2476)$ & (5) & Total organic carbon & (Zhu et al., 2008) \\
\hline 21 & Hidden Lake & Limestone & 1870 & (5) & $\begin{array}{l}\text { Aquatic plants, terrestrial } \\
\text { macrofossil }\end{array}$ & (Tang et al., 2004) \\
\hline 22 & Chabyer Caka & Limestone & $2000(2000-10000)$ & (2) & Total organic carbon & (Li et al., 2008) \\
\hline 30 & Lake Hurleg & Limestone & 2758 & (5) & Total organic carbon & (Zhao et al., 2007a) \\
\hline 31 & Ren Co & Limestone & 1870 & (4) & Total organic carbon & (Tang et al., 2004) \\
\hline 32 & Lake Sugan & & $2627(2627-4342)$ & (5) & Aquatic organic carbon & (Zhou et al., 2009) \\
\hline
\end{tabular}


estimates based on the linear regression approach from different coring sites within a single lake have been shown to differ significantly, implying variable sedimentation rates. For example, two cores from the southeastern sub-basin of Lake Qinghai (Core QH2000 and Core QH85-16A) have reservoir ages of 1039 and 439 years (Zhang et al., 1994; Shen et al., 2005) and a third core (Core QING6) from the southern sub-basin yielded a reservoir age of 737 years (Henderson et al., 2010) (Table 2).

\subsection{Geochemical models for ${ }^{14} \mathrm{C}$ reservoir correction}

${ }^{14} \mathrm{C}$ reservoir ages can be modeled when the various sources of carbon to lake water and their respective ${ }^{14} \mathrm{C}$ activities can be identified and quantified. Yu et al. (2007) developed a twocomponent box model based on the principle of ${ }^{14} \mathrm{C}$ mass balance in lake water and the early diagenetic zone to estimate the relative importance of terrestrial inputs, autochthonous production, and biogeochemical processes in the ${ }^{14} \mathrm{C}$ reservoir of a lacustrine system. When applied to Lake Qinghai, the model yields a reservoir age of 1500 years (Yu et al., 2007). Wang et al. (2007) adopted an equilibrium model based on the ${ }^{14} \mathrm{C}$ concentration in lake water and the atmosphere and calculated a modern reservoir age at Lake Qinghai of 1569 years. Using the model, they also estimated that the reservoir age has varied between 800 and 1650 years during the past 8000 years at Lake Qinghai (Wang et al., 2007). Such models provide a useful conceptual approach to estimating reservoir ages, however, they are limited by the degree to which geochemical cycling within a catchment is understood. Moreover, such models require additional information, which is not always available, about past changes in the geochemical balance of the lake (e.g., source changes for DIC) to effectively consider temporal changes in geochemical cycling within the system.

\subsection{Stratigraphic alignment}

Stratigraphic correlation between different proxy records (from lake sediment cores and other archives) has also been used as a technique to determine the ${ }^{14} \mathrm{C}$ reservoir age of lakes on the TP. For example, Liu et al. (2008) argued that the abrupt decrease in total organic carbon and total nitrogen measured in a sediment core from Caka Salt Lake coincides with the Younger Dryas (YD) interval. Assuming that the YD was globally synchronous, they assigned the age of the YD to the observed decrease in TOC and TN. Based on this single tie-point stratigraphic alignment and ${ }^{14} \mathrm{C}$ measurements from the sediment core, the reservoir age was estimated to be 1700 years at Caka Salt Lake (Table 2) (Liu et al., 2008). This approach potentially introduces very large errors to an ultimate age model, as it is built on the assumptions that 1) changes in a single sediment record can be accurately correlated to a climatic event expressed 1000's of kilometers away, and 2) the timing of the expression of that event is synchronous in distal locations. Stratigraphic alignment using the right core measurements can be a reasonable tool for correlating cores within a single lake or among proximal sites (Yu and Zhang, 2008). For instance, paleo-secular variation has been adopted to correlate different cores from Nam Co, and to establish chronologic control within the past 4000 years (Kasper et al., 2012). This is a reasonable approach because there are a priori reasons, unrelated to climate change, to expect paleo-secular variation changes to be coincident among different sites.

\subsection{Independent age determinations}

Comparison of ${ }^{14} \mathrm{C}$ ages with non-radiocarbon dating results, including ${ }^{210} \mathrm{~Pb}$ dating, ${ }^{137} \mathrm{Cs}$ dating, varve counting, or U-series dating of sediment is another approach used to calculate ${ }^{14} \mathrm{C}$ reservoir corrections. In this approach, the difference between ${ }^{14} \mathrm{C}$ based dates and the independent ages represents the reservoir age. U-series dating coupled with ${ }^{14} \mathrm{C}$ dating of surface sediments from Lake Luanhaizi reveals a ${ }^{14} \mathrm{C}$ reservoir age of $720 \mathrm{yr}$ (Mischke et al., 2005). The same approach applied to older core sections show reservoir ages greater than $6000 \mathrm{yr}$, and underscores the temporal instability of ${ }^{14} \mathrm{C}$ reservoir ages (Herzschuh et al., 2005, 2006a; Mischke et al., 2005). Liu et al. (2009) compared the ${ }^{210} \mathrm{~Pb}$-derived age and ${ }^{14} \mathrm{C}$-derived age at the same horizon at Lake Kusai, and found that the age difference is 3400 years (Liu et al., 2009). Based on the ${ }^{137} \mathrm{Cs}$ and ${ }^{210} \mathrm{~Pb}$-derived sedimentation rate of a core from Nam Co, Zhu et al. (2008) estimated the reservoir age of the sediment core varied from 2476 to 1200 years across the most recent $200 \mathrm{~cm}$ of deposition (Table 2) (Lin et al., 2008; Xie et al., 2008; Zhu et al., 2008). Terrestrial plant remains preserved in the lake sediments could reflect the real ages of sediment deposition because terrestrial plants utilize atmospheric $\mathrm{CO}_{2}$ during photosynthesis and are not influenced by a lake's reservoir effect. For example, Tang et al. (2004) estimated a reservoir age of 1870 years at Hidden Lake by comparing ${ }^{14} \mathrm{C}$ ages of aquatic and terrestrial macrofossils (Tang et al., 2004). Zhou et al. (2009) compared varve counting with ${ }^{14} \mathrm{C}$ ages on aquatic macrofossil to determine the modern RA is $2627 \mathrm{yr}$ in Lake Sugan, of which the aquatic macrofossil was apparently influenced by the reservoir effect significantly (Zhou et al., 2009).

Macroscopic fossils of terrestrial plants do not usually occur in most lakes on the TP due to very low vegetation cover. In the absence of terrestrial macrofossils, lignin phenols, which are unique to vascular plants and represent up to $30 \%$ of vascular plant woody biomass, can be used for radiocarbon measurements (Sarkanten and Ludwig, 1971). Hou et al. (2010) determined ${ }^{14} \mathrm{C}$ ages of lignin phenols in Lake Qinghai and found them younger than those of bulk organic matter, providing a reservoir correction varying from 700 to 1600 years throughout the core (Hou et al., 2010).

Each method discussed above has its own advantages and disadvantages with respect to lakes of the TP. The modern calibration approach and the linear extrapolation approach can only provide an estimate of the modern ${ }^{14} \mathrm{C}$ RA. Numerous studies from the TP have shown that the ${ }^{14} \mathrm{C}$ RA has varied, in some instances quite dramatically, during the Holocene. Therefore, applying a modern ${ }^{14} \mathrm{C}$ RA to an entire Holocene (or longer) sediment core introduces large errors to the age model and is inadequate. Geochemical modeling approaches can provide clues to the temporal variability of ${ }^{14} \mathrm{C}$ RA if changes in the geochemical cycle within the lake system can be quantitatively determined. It is difficult to justify age models based on stratigraphic alignment of different cores unless the parameter being used for correlation is known to vary in concert globally (or at least regionally) and will not itself be used to inform paleoclimate interpretation. Independent age determination is the most reliable approach for estimating past changes in ${ }^{14} \mathrm{C}$ RA. Furthermore, although it is often difficult to identify terrestrial macrofossils in lakes of the TP, without a way to assess changes in ${ }^{14} \mathrm{C}$ RA through time, the chronological uncertainties of any age model from a TP lake will dramatically limit its utility as a paleoclimate archive.

\section{Spatial and temporal patterns of reservoir ages on the TP}

\subsection{Spatial variation of reservoir ages}

Modern ${ }^{14} \mathrm{C}$ reservoir ages of lakes on the TP reported in the scientific literature are shown in Fig. 2. The reservoir ages vary significantly, ranging from 650 years at Ahung Co to 6670 years at 


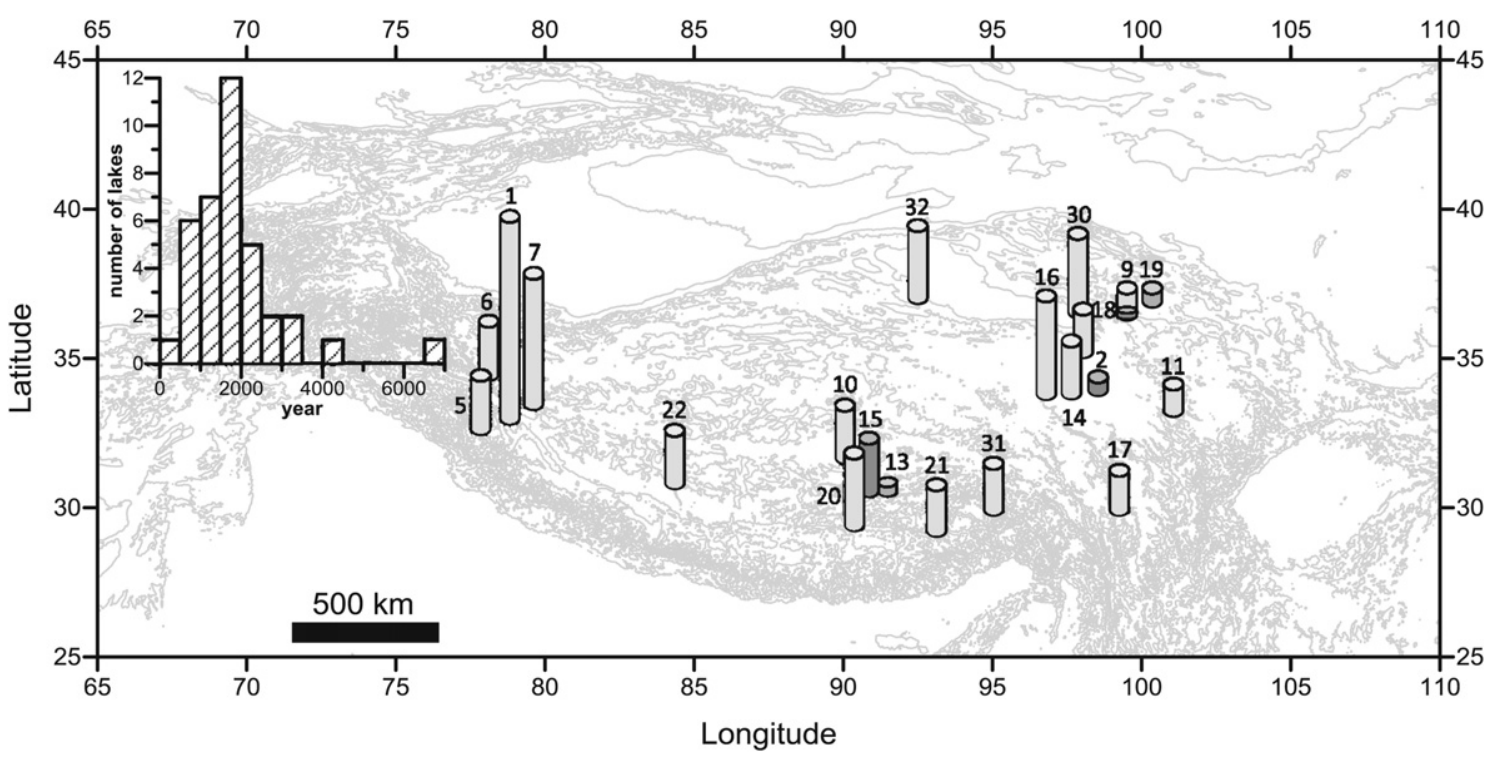

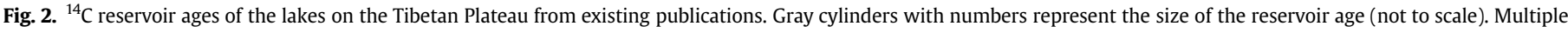

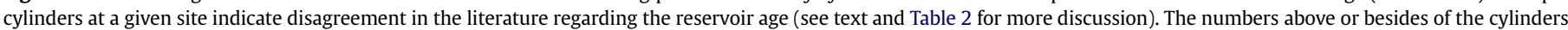
correspond to the lake IDs in Table 1 and Fig. 1. The insert histogram shows the distribution of the reservoir ages in current publications.

Bangong Co. The reservoir ages of most lakes range from 1000 to 3000 years (see Table 2 and Fig. 2). The geographic pattern of reservoir ages in TP lakes is likely due to a variety of factors, including bedrock geology, residence time of lake water, and the presence of peat or wetlands within a lake's catchment. Of these, bedrock geology is likely to exert the first order control on ${ }^{14} \mathrm{C}$ reservoir age (Table 2). For example, ${ }^{14} \mathrm{C}$-dead carbon from the carbonate bedrock surrounding Bangong Co provides more than $55 \%$ of the lake's DIC and results in a very large reservoir age (Fontes et al., 1996; Jiao et al., 2007). In contrast, the catchment of Lake Ahung Co comprises Mesozoic sedimentary and metasedimentary rocks (quartzite and shale) providing little to no ${ }^{14} \mathrm{C}$-dead carbon and the reservoir age of this lake is much smaller (Morrill et al., 2006; Jiao et al., 2007). The intermediate reservoir ages at other lakes can be understood largely in the context of catchment bedrock composition (Table 2). As a second order control, leaching of dissolved organic carbon from wetland environments within a lake's catchment can provide an important source of ${ }^{14} \mathrm{C}$-depleted carbon (Hatte and Jull, 2007).

\subsection{Variation of reservoir ages through time}

Many of the factors that determine ${ }^{14} \mathrm{C}$ reservoir age, including climatic controls on chemical weathering rates, vegetation cover and soil development vary through time and result in temporal changes in reservoir age (Watanabe et al., 2010a, 2010b). A number of studies from the TP have demonstrated that ${ }^{14} \mathrm{C}$ reservoir ages for certain lakes have, in fact, not remained fixed (Fig. 3). For example, Zhu et al. (2008) generated an age model for the upper $17.5 \mathrm{~cm}$ of sediment from Nam Co using ${ }^{210} \mathrm{~Pb}$ dating, and extrapolated the calculated sedimentation rate to $200 \mathrm{~cm}$. They then estimated the reservoir age as the offset between the extrapolated age and ${ }^{14} \mathrm{C}$ measurements on bulk sediment at the same depth. Assuming that their assumption of constant sedimentation rate was correct, the
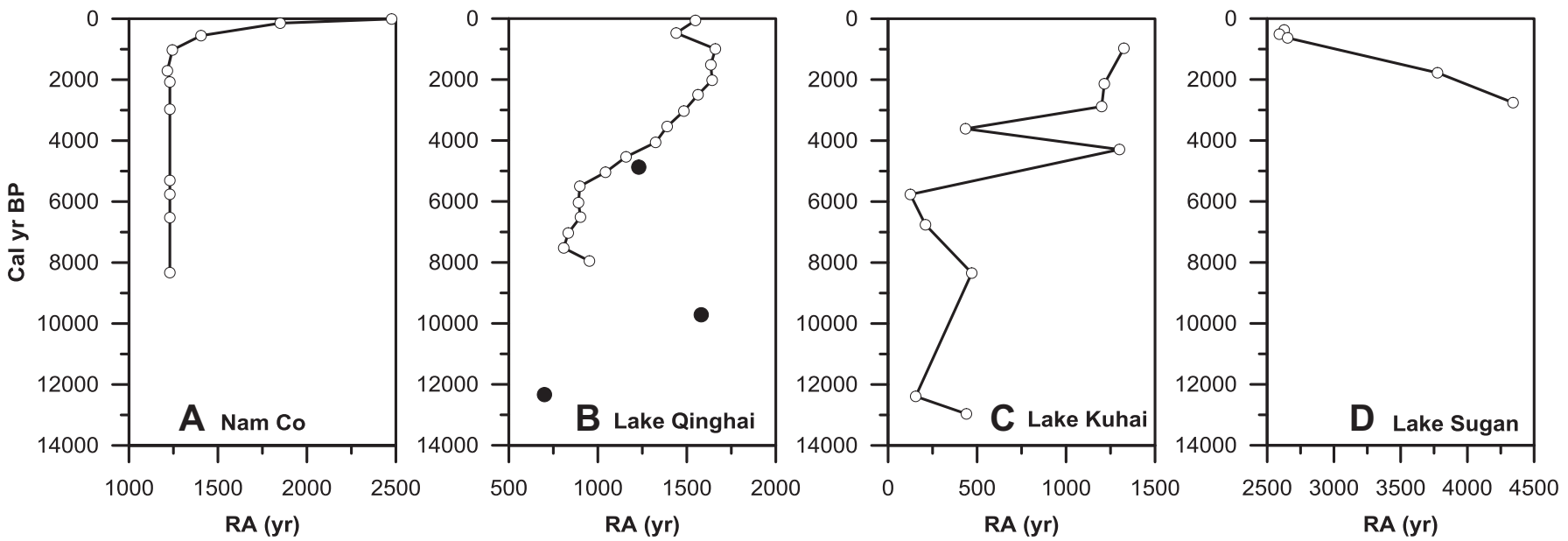

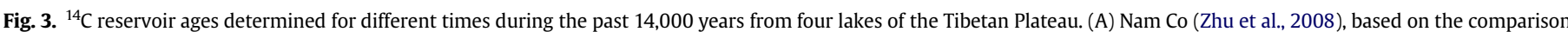

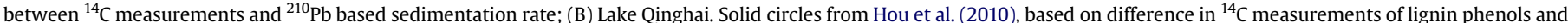

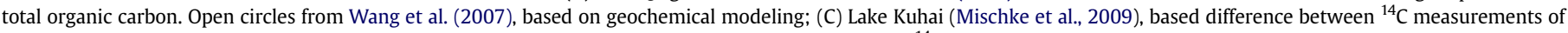
alkali insoluble and soluble fractions; (D) Lake Sugan (Zhou et al., 2009), based on varve counting and ${ }^{14} \mathrm{C}$ ages of aquatic plants. 
reservoir ages at Nam Co decreased dramatically with depth, from 2476 to 1200 years across the upper $200 \mathrm{~cm}$ sediment (Fig. 3A). At Lake Qinghai (Fig. 3B), Wang et al. (2007) argued that the reservoir ages decreased gradually from 1650 to 800 years between 1000 and 7000 cal yr BP. Mischke et al. (2009) radiocarbon dated alkali insoluble and soluble fractions from the sediment at Lake Kuhai and concluded the ${ }^{14} \mathrm{C}$ ages of the soluble fraction were less subject to ${ }^{14} \mathrm{C}$ reservoir effects because of their relatively young age relative to the insoluble fraction (Fig. 3C). Varve counts combined with ${ }^{14} \mathrm{C}$ dates from aquatic macrofossils at Lake Sugan (Zhou et al., 2009) reveal that the ${ }^{14} \mathrm{C}$ reservoir changed from 2627 to 4342 years, during the late Holocene (Fig. 3D). Furthermore, there is evidence that the ${ }^{14} \mathrm{C}$ reservoir ages during the last glacial period were very different from the modern reservoir ages. For example, Wang et al. (2002) determined a reservoir age of about 10,000 years at depth of $1.59-1.67 \mathrm{~m} \mathrm{(}{ }^{14} \mathrm{C}$ age $17,000 \pm 250$ years), which is much larger than the modern reservoir age of 2000 years (Li et al., 2008).

Existing chronologies for lake sediment cores have predominantly been constructed by subtracting a modern reservoir age from the downcore ${ }^{14} \mathrm{C}$ ages. However, as discussed above modern reservoir ages likely do not fully depict the past variation, or even the average value, of the downcore reservoir ages. Temporal changes of ${ }^{14} \mathrm{C}$ reservoir age have not been determined for most lakes on the TP, making it impossible to accurately estimate the resulting chronological uncertainties. For the following discussion, in cases where no additional information was available, two assumptions were made: 1) the modern reservoir age estimates were taken as the maximal reservoir ages throughout the sediment core; 2 ) the minimal allowable reservoir ages were zero. At the onset of lake development, the reservoir age of a freshwater lake should be negligible, as it would result primarily from the residence time of lake water (Stein et al., 2004). In the absence of additional information, we will therefore adopt a simple model of DIC accumulation through time wherein ${ }^{14} \mathrm{C}$ reservoir age increases from 0 at the time of initial lake development to its modern value. Within this framework, the modern reservoir age can be considered as the maximum uncertainty in the age model. We note that the first assumption potentially underestimates the chronological uncertainty and the second assumption potentially overestimates the uncertainty.

\section{Chronological uncertainty and inferred patterns in climate change on the TP}

To demonstrate the influence of chronological uncertainties deriving from ${ }^{14} \mathrm{C}$ reservoir effect on the interpretation of climate records, we present two case studies: one from Bangong Co and one from Lake Qinghai. Bangong Co has the largest reported modern reservoir age (6670 year) of TP lakes and the ${ }^{14} \mathrm{C}$ reservoir ages at Lake Qinghai have been estimated using various techniques (Table 2).

\subsection{Bangong Co}

Bangong $\operatorname{Co}\left(79.83^{\circ} \mathrm{E}, 33.51^{\circ} \mathrm{N}, 4243 \mathrm{~m}\right.$ asl $)$ is the largest lake on the western Tibetan Plateau and has been studied in great detail (Fan et al., 1996; Fontes et al., 1996; Gasse et al., 1996; van Campo et al., 1996). A $12.4 \mathrm{~m}$ sediment core was collected in 1989 at $5 \mathrm{~m}$ water depth near eastern shoreline, representing the past $11 \mathrm{cal} \mathrm{ka}$ of sedimentation. The core was analyzed for mineralogy, $\delta^{18} \mathrm{O}$ and $\delta^{13} \mathrm{C}$ of authigenic carbonates (Fontes et al., 1996), pollen (van Campo et al., 1996), organic compounds, diatoms, ostracods and charophytes (Fan et al., 1996). Two abrupt shifts are present in the Bangong $\delta^{18} \mathrm{O}$ records (Fig. 4A); one from high to low $\delta^{18} \mathrm{O}$ values at ca $11 \mathrm{cal}$ ka $\mathrm{BP}$, and the other from low to high $\delta^{18} \mathrm{O}$ values at $1.3 \mathrm{cal}$ ka BP (Gasse et al., 1996). These changes have been attributed
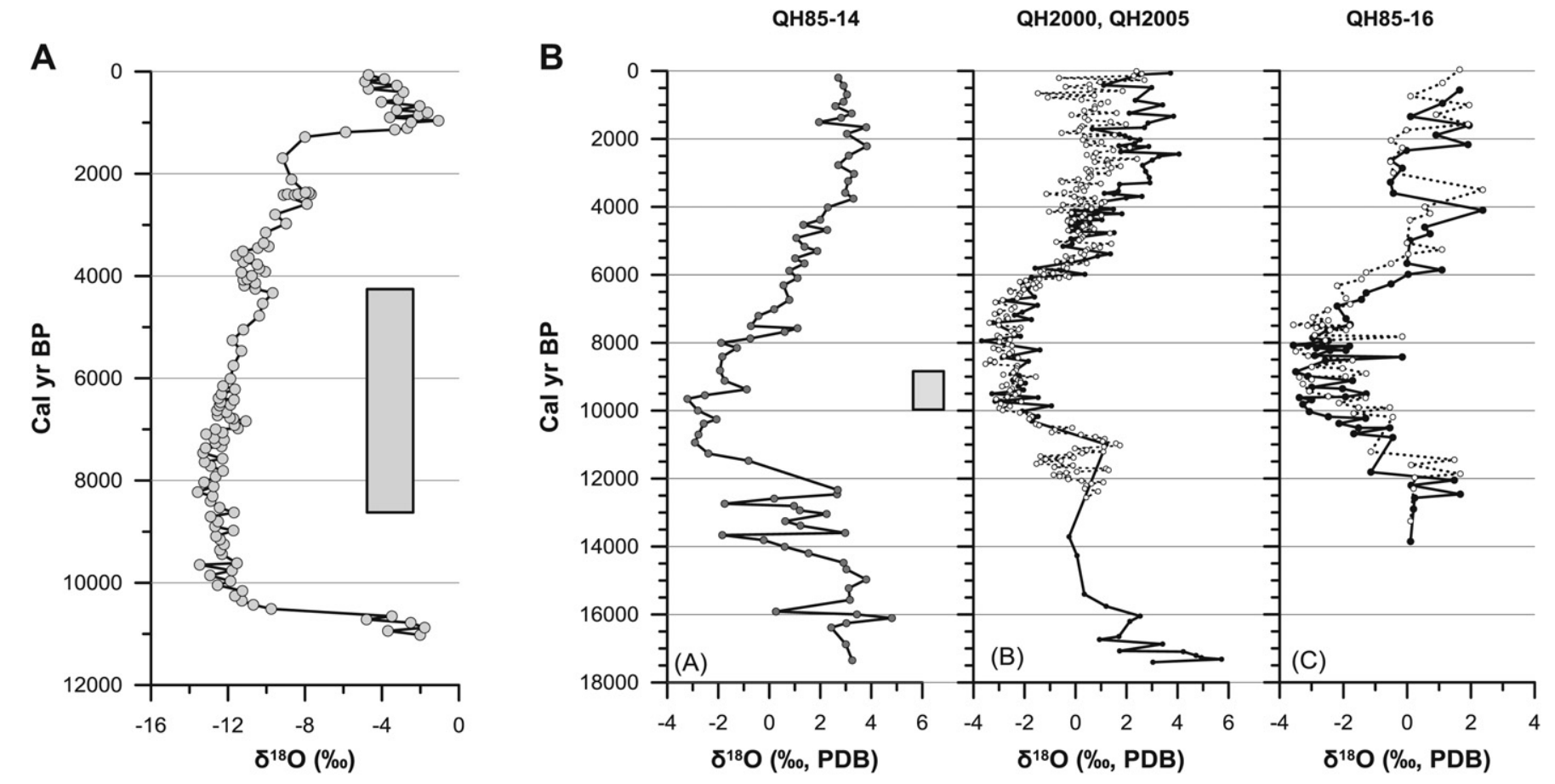

QH2000, QH2005

QH85-16

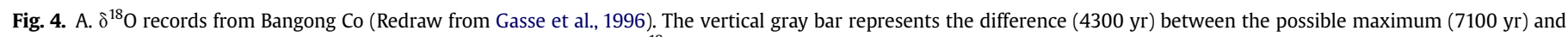

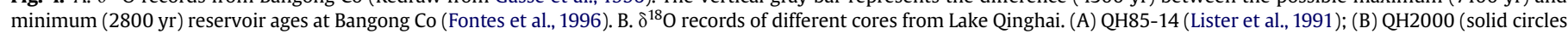

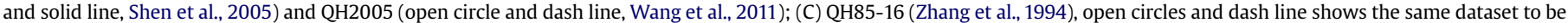

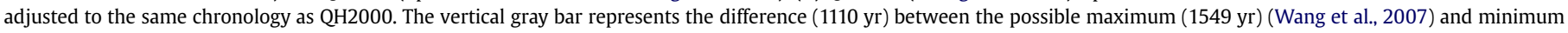
(439 yr) (Zhang et al., 1994) reservoir ages at Lake Qinghai. 
to the hydrologic opening and closure of the lake, respectively. Relatively low $\delta^{18} \mathrm{O}$ values from 10.5 to $7.2 \mathrm{cal} \mathrm{ka} \mathrm{BP}$ are interpreted to reflect an enhanced monsoon due to strong solar insolation (Gasse et al., 1996; Wei and Gasse, 1999). The overall increase in $\delta^{18} \mathrm{O}$ from 7.2 to $1.3 \mathrm{cal} \mathrm{ka}$ BP is interpreted as a weakening of the monsoon and change in the origin of atmospheric moisture, from monsoonal origin to locally re-evaporated moisture with higher ${ }^{18} \mathrm{O}$ content (Gasse et al., 1996; Wei and Gasse, 1999).

The reservoir age of 6670 years was determined by linear extrapolation to the sediment-water surface of twelve ${ }^{14} \mathrm{C}$ ages below $200 \mathrm{~cm}$ in the sediment core at Bangong Co (Fontes et al., 1996). The ${ }^{14} \mathrm{C}$ ages of modern lake water were ca 3200 and 5700 ${ }^{14} \mathrm{C}$ years at the eastern and northern margin of the eastern Bangong basin. The ${ }^{14} \mathrm{C}$ ages of water at three major tributaries differ significantly; 2800 years for Nama Chu, 3100 years for Makha, and 7100 years for Chiao Ho (Fontes et al., 1996). Changes in the relative hydrologic contributions of the tributaries may significantly alter the ${ }^{14} \mathrm{C}$ age of lake water, which suggests that the reservoir age of the Bangong Co may vary from ca 2800 years to ca 7100 years at different stages. As noted in Fontes et al. (1996), the ${ }^{14} \mathrm{C}$ ages above $200 \mathrm{~cm}$ deviate significantly from the linear regression and may reflect changes in ${ }^{14} \mathrm{C}$ reservoir ages. However, in the absence of additional information, a constant reservoir age was subtracted to construct the chronology for the sediment core (Fontes et al., 1996). The following discussion considers viable paleoclimatic interpretations based on the $\delta^{18} \mathrm{O}$ records from Bangong Co considering the full range of chronological uncertainty (allowing a ${ }^{14} \mathrm{C}$ reservoir age ranging from 2800 to 7100 years).

The relatively low $\delta^{18} \mathrm{O}$ values between 10.5 and 7.2 cal ka were assigned to the Holocene Thermal Maximum (HTM, Fig. 4A) characterized by an enhanced monsoon (Gasse et al., 1996). However, the enhanced monsoon at Bangong Co may begin as early as $14.4 \mathrm{ka}$ $\mathrm{BP}$ and end as early as $11.1 \mathrm{ka} \mathrm{BP}$ if the smallest reservoir age of 2800 yrs is applied. This apparently contradicts the synthesis and interpretation of limnological $\delta^{18} \mathrm{O}$ records across the TP (Fig. 4A) by Wei and Gasse (1999), which argues for a rapid establishment of isotopically enriched precipitation across the TP around $12 \mathrm{ka}$ BP when the Indian monsoon reached the northwest TP. The timing of hydrological opening and closure of Bangong $\mathrm{Co}$, which is currently assigned at 10.5 and 1.3 cal ka BP (Gasse et al., 1996), can also change significantly within chronological uncertainties. The timing of the lake opening and closure would be 14.4 and 5.2 cal ka BP, respectively, if a small reservoir age of 2800 years were adopted. In this case, the climate scenarios revealed by the multiple records at Bangong Co may require reinterpretation to account for variable reservoir ages. If this is the case, syntheses of paleoclimate records on the TP that incorporate Bangong records (Wei and Gasse, 1999) also need reinterpretation.

\subsection{Lake Qinghai}

Lake Qinghai $\left(100.16^{\circ}, 36.88^{\circ}, 3200 \mathrm{~m}\right.$ asl) is located in the northeastern TP (Fig. 1). Multiple sediment cores have been recovered from the lake during the past 50 years and various ${ }^{14} \mathrm{C}$ reservoir ages have been determined for the lake (Table 2). Core QH85-14B was recovered from the southern lake basin (Lister et al., 1991), while cores QH85-16B, QH2000 and QH2005 were recovered from the southeastern sub-basin (Zhang et al., 1994; Shen et al., 2005; Wang et al., 2011). Notably, core QH85-14B from the southern basin and Core QH2000 from the southeastern sub-basin show similar modern ${ }^{14} \mathrm{C}$ reservoir ages (1100 years and 1039 years). However, the modern ${ }^{14} \mathrm{C}$ reservoir age determined for Core QH85-16B is approximately 600 years smaller than that for QH2000 and QH2005, both of which are from the southeastern sub-basin. The $\delta^{18} \mathrm{O}$ records of $\mathrm{QH} 2000$ and $\mathrm{QH} 2005$ are very similar based on the chronological controls that were corrected with RA of 1039 years. However, the $\delta^{18} \mathrm{O}$ records of QH85-16 of which RA is 439 years show slightly shift in timing for the HTM. If the ages for core QH85-16B, QH2000 and QH2005 are subtracted by a same reservoir age, for example, taking the RA as 1039 years for three cores, the $\delta^{18} \mathrm{O}$ records show striking similarity (Fig. 4B).

The timing of abrupt climate events at Lake Qinghai may vary significantly if variable ${ }^{14} \mathrm{C}$ reservoir ages are used to construct the chronology, although the general trend of the climate revealed by the $\delta^{18} \mathrm{O}$ records may not differ significantly from the climate scenarios interpreted in current publications. The timing of the abrupt climate events, such as the termination of Last Glacial Maximum, the Younger Dryas (Yu and Kelts, 2002) and the possible 8.2 ka event (Ji et al., 2005) revealed by records of pollen and sediment redness at Lake Qinghai would differ more than 600 years relative to the current chronology based on a constant reservoir age correction. An age offset of more than 600 years would make it difficult to assign the decline in redness to $8.2 \mathrm{ka}$ event.

\subsection{The influence of chronological control on the observed patterns of climate change on the TP}

Fig. 5A shows selected published paleolimnological records from the TP that span the past 20,000 years. In order to examine the impact of chronological uncertainties resulting from existing reservoir age corrections on accurate interpretation of patterns of past climate change, we will focus on two major climate events: the termination of the Last Glacial Maximum (LGM) and the timing of the HTM. We include the $\delta^{18} \mathrm{O}$ record from the Guliya ice core in Fig. 5A and B. While a discussion of the errors of ice core chronologies is beyond the scope of this paper, it is important to recognize that ice thinning precludes layer counting of the Guliya ice core prior to approximately 2,000 years BP. For the period before that, Guliya age modeling is based on visual correlation of glacialinterglacial changes in Guliya $\delta^{18} \mathrm{O}$ with $\delta^{18} \mathrm{O}, \mathrm{CH}_{4}$ and $\mathrm{CO}_{2}$ from polar ice cores and is therefore subject to very large uncertainties for the period 20,000 to 2000 years BP (Thompson et al., 1997).

\subsubsection{The timing of the LGM termination}

The timing of the LGM termination inferred from lacustrine records on the TP varies significantly (Fig. 5A). One general trend in LGM timing appears to be that the interior lakes show later termination, with the westernmost lakes of the western TP and the easternmost lakes of the eastern TP having the earliest inferred terminations (Fig. 5A). For example, on the western TP the LGM at Lake Hongshan terminated ca 18,300 cal yr BP (Li et al., 1994), Nyer Co ca 18,100 cal yr BP (Liu et al., 2007) and Chabyer Caka ca 16,800 cal yr BP (Zheng et al., 2007) (Fig. 5A). The LGM terminated ca 14,300 yr BP at Peiku Co (not shown in the Fig. 5A) (Peng, 1997; Huang, 2000). On the eastern TP, the LGM at Lake Luanhaizi and Ximen Co terminated ca 20,000 and 19,000 yr BP, respectively (Herzschuh et al., 2006a; Zhang and Mischke, 2009), and the termination ages from the lakes farther west are younger (Lake Qinghai ca 17,000 cal yr BP (Lister et al., 1991; Shen et al., 2005), Lake Kuhai ca 15,000 cal yr BP (Mischke et al., 2009) and Lake Koucha ca 16,300 cal yr BP (Mischke et al., 2008) (Fig. 5).

Globally, the LGM is considered to have occurred between 23,000 and 19,000 cal yr BP (Clark and Mix, 2002), as the result of changing northern Hemisphere summer insolation, although the LGM termination precedes the insolation maximum by several thousands of years (Paillard, 1998; Paillard and Parrenin, 2004). The inferred ages of LGM termination from lacustrine records of the TP are based on proxy measurements interpreted as responses to large and abrupt changes in temperature, precipitation and/or catchment-specific environmental conditions. 
A

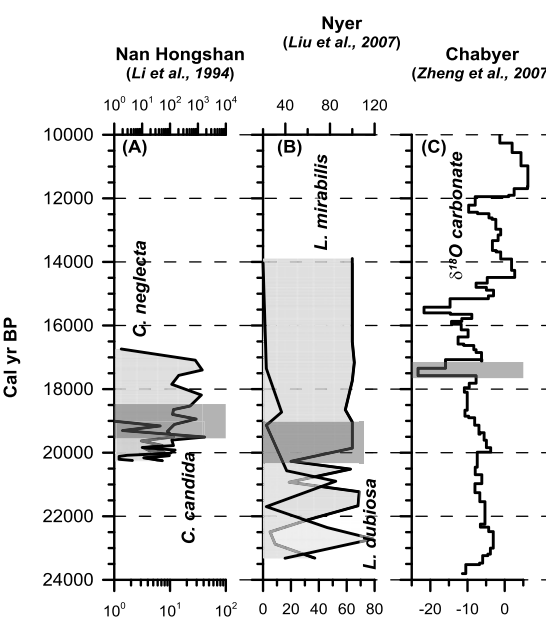

Guliya
$\begin{gathered}\text { Koucha } \\ \text { (Thompson et al., 1995) } \\ \text { Gu'nong } \\ \text { (Hu et al., 2006) }\end{gathered}$
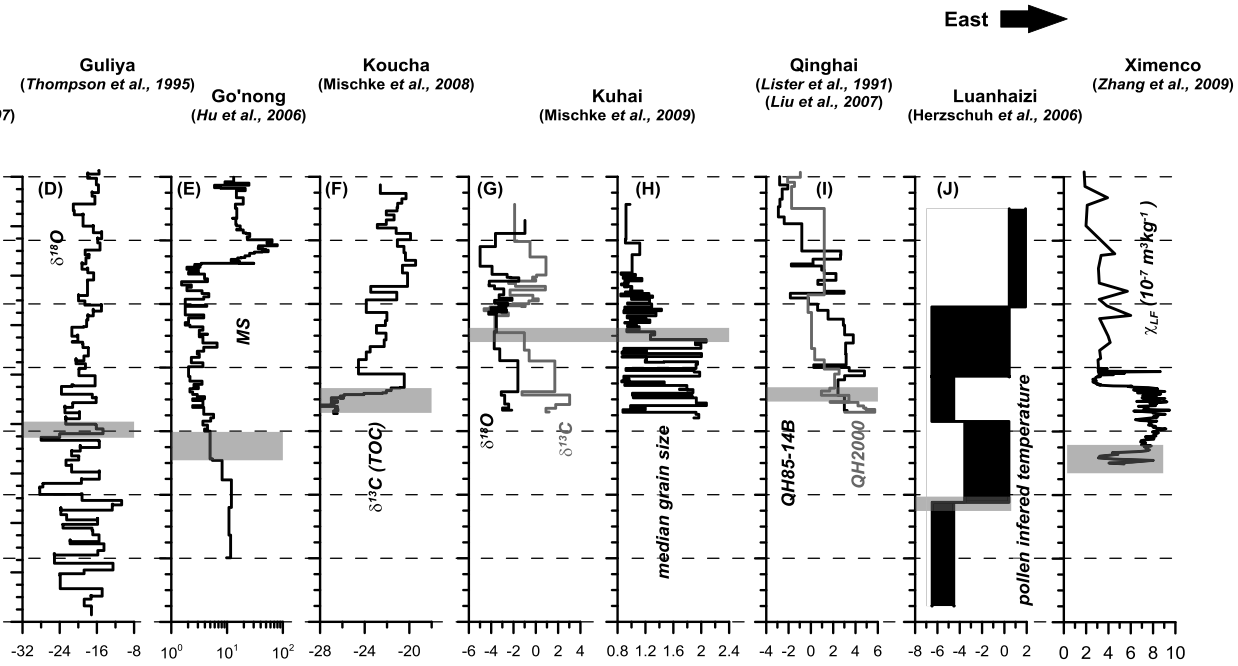

B
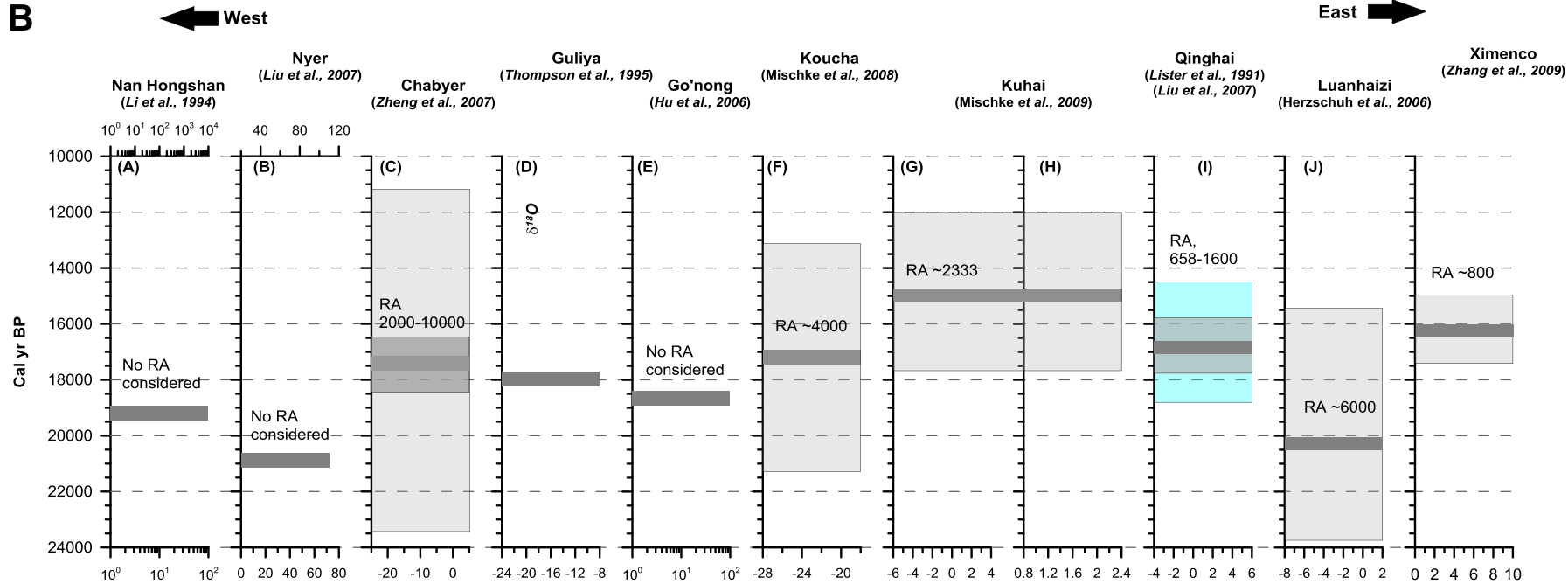

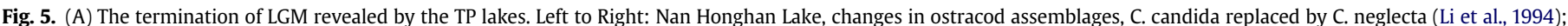

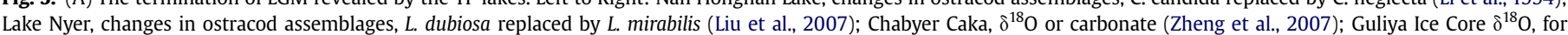

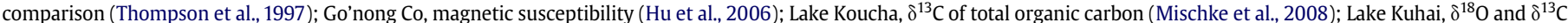

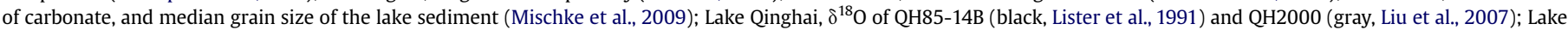

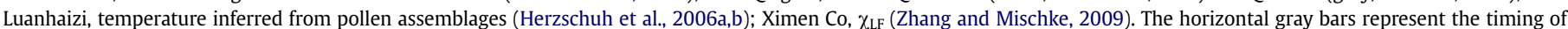

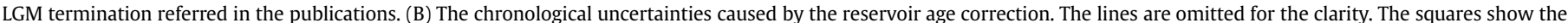

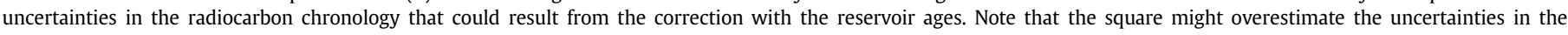
chronology (see text for discussion).

How then, are the observed spatial patterns of LGM termination in current publications from the TP explained? According to the general climatology of the TP, changes in the East Asian Monsoon, the Indian Monsoon and the westerlies should be responsible for the climate responses observed in the proxy records. Intensification of the East Asian Monsoon associated with increasing summer insolation (Porter and An, 1995; An et al., 2000, 2001; Porter, 2001) would have caused higher temperature and increased summer precipitation, preferentially influencing the eastern margin of TP and potentially explaining the early timing of observed changes in the proxy records from Lake Luanhaizi, Ximen Co, and Lake Qinghai. However, the younger ages of LGM termination from the western lakes suggest that the western and central TP were not significantly impacted by intensification of the East Asian Monsoon at this time. Instead, these regions were possibly still primarily controlled by the climatology of the westerlies. The relative influence of the westerlies on the climate of the central and western TP could have eventually given way to the East Asian Monsoon as it further intensified with continued increase of Northern Hemisphere solar radiation. The late LGM termination on the western and central TP may have resulted from the increased precipitation brought by the westerlies during this climate transition (Chen et al., 2008). The westerly circulation may strengthen and make the climate in western and central TP mild and terminate the LGM. The strength of the westerlies is chiefly influenced by North Atlantic sea surface temperature and the high latitude temperature (Chen et al., 2008), which increased with the increasing northern hemisphere solar insolation (Kandiano et al., 2004).

\subsubsection{Spatial patterns of Holocene Thermal Maximum}

The HTM is a feature widely recognized in paleoclimate records from the TP and is characterized as a period of enhanced monsoon, increased precipitation, and/or increased temperature (References cited in this section). In this review, we adopted the timing of the HTM specified in the references. The spatial pattern of the timing of the HTM inferred from the lake records of the TP differs from that of 


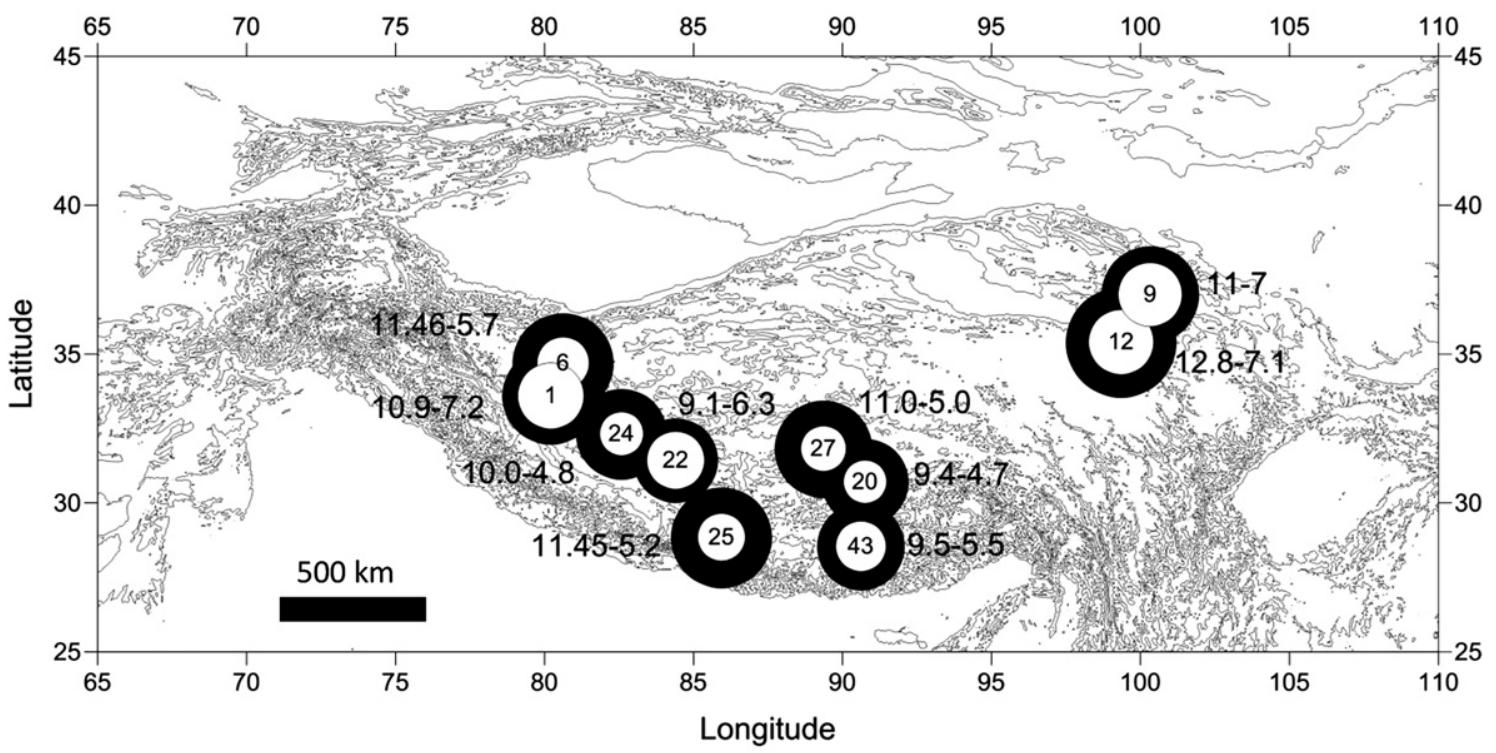

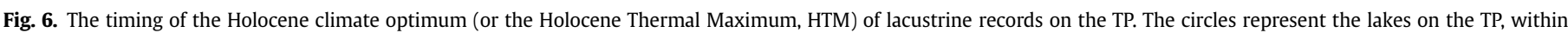

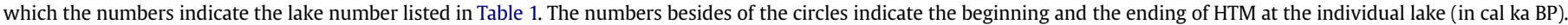
The thickness of the circles represents the duration of the HTM (not to scale).

the LGM termination (Fig. 6). On the western TP, the HTM appears to have proceeded eastward through time, beginning approximately 11,460 yr BP at the westernmost site, Sumxi Co (Gasse et al., 1991) and progressing eastward to Bangong Co and Nyer Co at 10,900 yr BP (Gasse et al., 1996; Liu et al., 2007) and Chabyer Caka, the easternmost site of the western TP, ca 9100 cal yr BP (Zheng et al., 2007). The HTM inferred from lakes on the central TP also apparently progressed from west to east, moving from Peiku Co ca 11,450 cal yr BP (Peng, 1997; Huang, 2000) to Serling Co ca 11,000 cal yr BP (Gu et al., 1993), Nam Co ca 9400 cal yr BP (Schütt et al., 2010) and Puma Yumco ca 9500 cal yr BP (Watanabe et al., 2010a, 2010b). The HTM inferred from the two lakes on the eastern TP occurred early, ca 11,000 cal yr BP at Lake Qinghai (Shen et al., 2005) and ca 12,800 cal yr BP at Lake Kuhai (Mischke et al., 2009). Based on observations from existing paleolimnological records the climate of the western TP was probably primarily controlled by the westerlies during the HTM. As suggested by Chen et al. (2008), the westerlies dominated the climate of the western TP, while the monsoon systems influenced central and eastern TP during the Holocene. On the western TP, the influence of the westerlies progressed eastward to Chabyer Caka during the early Holocene, and retreated westward during the middle Holocene. In the central and eastern $\mathrm{TP}$, the monsoon systems progressed westward and then retreated eastward, resulting in the observed spatial-temporal pattern of HTM timing and consistent with the reconstructed patterns of maximal monsoon precipitation during the Holocene (An et al., 2000).

\subsubsection{Chronological uncertainty and spatial interpretation of TP paleoclimate}

The patterns of climate change and inferred changes in the climate systems discussed in Sections 5.3.1 and 5.3.2 are based on the chronologies reported in the published papers. However, due to uncertainties in the ${ }^{14} \mathrm{C}$ reservoir ages, the accuracy of these chronologies is questionable. As discussed earlier, it is almost certainly incorrect to apply a modern ${ }^{14} \mathrm{C}$ reservoir age correction to an entire sediment core. Fig. 5B shows the possible timing of LGM termination if the maximal uncertainties in the chronology are considered. For example, the LGM termination reflected by changes in proxy records may vary between $19 \mathrm{ka}$ and $15 \mathrm{ka} \mathrm{BP}$ at Chabyer Caka $\left({ }^{14} \mathrm{C}\right.$ RA is 2000 years (Li et al., 2008)) or 28 to $8 \mathrm{ka} \mathrm{BP}\left({ }^{14} \mathrm{C} \mathrm{RA}\right.$ is approximately 10,000 years during the Lateglacial (Wang et al., 2002)), between $21 \mathrm{ka}$ and $13 \mathrm{ka} \mathrm{BP}$ at Koucha (RA is about 4000 years at deeper core (Mischke et al., 2008)), between $17 \mathrm{ka}$ and $13 \mathrm{ka}$ BP at Lake Kuhai (RA is 2333 or 867 years (Mischke et al., 2009)), between 26 and $14 \mathrm{ka} \mathrm{BP}$ at Lake Luanhaizi (RA is about 6000 years during the Lateglacial (Herzschuh et al., 2006a)). In this case, the climate dynamics discussed in Section 5.3.1 for the LGM termination would be invalid and there would be no clear spatial trend in LGM termination (Fig. 5B). This also applies for the timing of the HTM across the TP. The true uncertainties in the age models of TP lakes, resulting from uncertainties in the ${ }^{14} \mathrm{C}$ reservoir ages during the past 20,000 years, therefore severely limit the utility of these paleoclimate records for examining the climate dynamics of this important region.

\section{Conclusion}

The ${ }^{14} \mathrm{C}$ reservoir ages of lakes on the Tibetan Plateau show significant spatial and temporal variability. Catchment bedrock composition likely is the primary control on the ${ }^{14} \mathrm{C}$ reservoir ages across the Tibetan Plateau (which ranges from 7000 years to a couple of hundreds of years), with DOC contributions from peat deposits and water residence time exerting a lesser influence. Temporal changes in the ${ }^{14} \mathrm{C}$ reservoir age of individual lakes have been reported for a few lakes on the Plateau, highlighting the inadequacy of applying a modern ${ }^{14} \mathrm{C}$ reservoir correction to a late Quaternary sediment record.

However, ${ }^{14} \mathrm{C}$-based chronological controls of most lake sediment records from the Tibetan Plateau have been corrected for the reservoir effect by applying the modern reservoir age correction. This approach contributes undeterminable uncertainty to the age model for different sections of the sediment core since lake ontogeny, climate and hydrological change all impact the ${ }^{14} \mathrm{C}$ reservoir age of lake water. ${ }^{14} \mathrm{C}$ reservoir ages on the TP have been shown to vary by as much as 5000 years in a single lake between deglaciation and the late Holocene. Although the climate evolution inferred from a single lake may be informative (with large 
chronological uncertainties) any spatial-temporal patterns in the climate change based on syntheses of numerous lake records are effectively meaningless given the large chronological uncertainties. Due to the importance of developing more well-dated, high resolution, quantitative paleoclimate records from lakes for understanding TP climate dynamics, it is imperative that any study with this objective include plans to minimize the chronologic uncertainty from the ${ }^{14} \mathrm{C}$ reservoir. Researchers should have a specific plan for independent age determination, by dating terrestrial macrofossils or lignin phenols, or making regular determinations of the ${ }^{14} \mathrm{C}$ reservoir, not only for the modern lake, but throughout the time period of interest.

\section{Acknowledgments}

This work is supported by grants from the National Natural Science Foundation of China (NSFC Grant No. 41072120), Innovation Program at the Chinese Academy of Science (Grant No. KZCX2-YWJC106), NSFC Innovation Research Group Fund (Grant No. 41021001), and State Key Laboratory of Loess and Quaternary Geology (SKLLQG0917) to J Hou. J Hou is supported by the "100 Talents Program" at the Chinese Academy of Sciences. We thank an anonymous reviewer and Prof. J. Dodson for their critical comments and editor for his helpful reviews.

\section{Appendix A. Supplementary material}

Supplementary material associated with this article can be found, in the online version, at http://dx.doi.org $/ 10.1016 / \mathrm{j}$. quascirev.2012.06.008.

\section{References}

An, Z.-S., Porter, S.C., Kutzbach, J.E., Wu, X.-H., Wang, S.-M., Liu, X.-D., Li, X.-Q Zhou, W.-J., 2000. Asynchronous Holocene optimum of the East Asian monsoon. Quaternary Science Reviews 19, 743-762.

An, Z.-S., Kutzbach, J.E., Prell, W., Porter, S.C., 2001. Evolution of Asian monsoons and phased uplift of the himalaya-Tibetan Plateau since Late Miocene times. Nature 411, 62-66.

Barnett, T.P., Adam, J.C., Lettenmaier, D.P., 2005. Potential impacts of a warming climate on water availability in snow-dominated regions. Nature 438, 303-309.

Cai, Y.-J., Cheng, H., An, Z.-S., Edwards, R.L., Wang, X.-F., Tan, L.-C., Wang, J., 2010. Large variations of oxygen isotopes in precipitation over south-central Tibet during Marine Isotope Stage 5. Geology 38, 243-246.

Chen, F.-H., Yu, Z.-C., Yang, M.-L., Ito, E., Wang, S.-M., Madsen, D.B., Huang, X.-Z., Zhao, Y., Sato, T., Birks, H.J.B., Boomer, I., Chen, J.-H., An, C.-B., Wünnemann, B., 2008. Holocene moisture evolution in arid central Asia and its out-of-phase relationship with Asian monsoon history. Quaternary Science Reviews 27, 351-364.

Clark, P.U., Mix, A.C., 2002. Ice sheets and sea level of the Last Glacial Maximum. Quaternary Science Reviews 21, 1-7.

Demske, D., Tarasov, P.E., Wünnemann, B., Riedel, F., 2009. Late glacial and Holocene vegetation, Indian monsoon and westerly circulation in the Trans-Himalaya recorded in the lacustrine pollen sequence from Tso Kar, Ladakh, NW India. Palaeogeography Palaeoclimatology Palaeoecology 279, 172-185.

Fan, H., Gasse, F., Huc, A., Li, Y.-F., Sifeddine, A., Soulié-Märsche, I., 1996. Holocene environmental changes in Bangong Co basin (western Tibet). Part 3: biogenic remains. Palaeogeography Palaeoclimatology Palaeoecology 120, 65-78.

Fontes, J.C., Mélières, F., Gibert, E., Liu, Q., Gasse, F., 1993. Stable isotope and radiocarbon balances of two Tibetan lakes (Sumxi Co, Longmu Co) from 13000 BP. Quaternary Science Reviews 12, 875-887.

Fontes, J.C., Gasse, F., Gibert, E., 1996. Holocene environmental changes in Lake Bangong basin (Western Tibet). Part 1: chronology and stable isotopes of carbonates of a Holocene lacustrine core. Palaeogeography Palaeoclimatology Palaeoecology 120, 25-47.

Gasse, F., Arnold, M., Fontes, J.C., Fort, M., Gibert, E., Huc, A., Li, B.-Y., Li, Y.-F., Liu, Q., Mélières, F., van Campo, E., Wang, F.-B., Zhang, Q.-S., 1991. A 13000 year climate record from western Tibet. Nature 353, 742-745.

Gasse, F., Fontes, J.C., van Campo, E., Wei, K., 1996. Holocene environmental changes in Bangong Co basin (western Tibet). Part 4: discussion and conclusions. Palaeogeography Palaeoclimatology Palaeoecology 120, 79-92.

Gu, Z.-Y., Liu, J.-Q., Yuan, B.-Y., Liu, T.-S., Liu, R., Liu, Y., Zhang, G., Yasukawa, K., 1993. The changes in monsoon influence in the Qinghai-Tibet Plateau during the past 12000 years: Geochemical evidence from the Lake Seling sediments. Chinese Science Bulletin 38, 61-64 (in Chinese).
Hatte, C., Jull, A.J.T., 2007. Radiocarbon dating: plant macrofossils. In: Elias, S.A. (Ed.), Encyclopedia of Quaternary Science. Elsevier Science, pp. 2958-2965.

He, Y., Theakstone, W.H., Zhang, Z.-L., Zhang, D., Yao, T.-D., Chen, T., Shen, Y.-P., Peng, H.-X., 2004. Asynchronous Holocene climatic change across China. Quaternary Research 61, 52-63.

Henderson, A.C.G., Holmes, J.A., 2009. Palaeolimnological evidence for environmental change over the past millennium from Lake Qinghai sediments: a review and future research prospective. Quaternary International 194, 134-147.

Henderson, A.C.G., Holmes, J.A., Leng, M.J., 2010. Late Holocene isotope hydrology of Lake Qinghai, NE Tibetan Plateau: effective moisture variability and atmospheric circulation changes. Quaternary Science Reviews 29, 2215-2223.

Herzschuh, U., Zhang, C.-J., Mischke, S., Herzschuh, R., Mohammadi, F., Mingram, B., Kürschner, H., Riedel, F., 2005. A late Quaternary lake record from the Qilian Mountains (NW China): evolution of the primary production and the water depth reconstructed from macrofossil, pollen, biomarker, and isotope data. Global and Planetary Change 46, 361-379.

Herzschuh, U., Kürschner, H., Mischke, S., 2006a. Temperature variability and vertical vegetation belt shifts during the last $\sim 50000 \mathrm{yr}$ in the Qilian mountains (NE margin of the Tibetan Plateau, China). Quaternary Research 66, 133-146.

Herzschuh, U., Winter, K., Wünnemann, B., Li, S.-J., 2006b. A general cooling trend on the central Tibetan Plateau throughout the Holocene recorded by the Lake Zigetang pollen spectra. Quaternary International 154-155, 113-121.

Hou, J.-Z., Huang, Y.-S., McNichol, A.P., Brodsky, C., Alexandre, M.R., King, J.W., 2010. Radiocarbon dating of individual lignin phenol compounds from wood and sediment and the potential applications in paleoenvironmental studies. Analytical Chemistry 82, 7119-7126.

Hu, D.-S., Zhang, H.-J., Xu, B., Li, B.-Y., Kong, Z.-C., Wen, J.-C., 2006. Lake sediments responded for the ancient monsoonal change of the late Quaternary period in the inland of Qinghai-Xizang Plateau. Arid Land Geography 29, 483-489 (in Chinese with English Abstract).

Huang, F., 2000. Vegetation and climate between 13 ka to 5 ka BP in Peiku Co, Tibet. Acta Palaeontologica Sinica 39, 441-448 (in Chinese with English Abstract).

Ji, J.-F., Shen, J., Balsam, W., Chen, J., Liu, L.-W., X-Q, L., 2005. Asian monsoon oscillations in the northeastern Qinghai? Tibet Plateau since the late glacial as interpreted from visible reflectance of Qinghai Lake sediments. Earth and Planetary Science Letters 233, 61-70.

Ji, J.-F., Balsam, W., Shen, J., Wang, M., Wang, H.-T., Chen, J., 2009. Centennial blooming of anoxygenic phototrophic bacteria in Qinghai Lake linked to solar and monsoon activities during the last 18,000 years. Quaternary Science Reviews 28, 1304-1308.

Jiao, S.-P., Zhang, Y.-F., Yi, S.-X., Ai, C.-X., Zhao, Y.-N., Li, Y.-M., Wang, H.-D., Xu, J.-E., Hu, J.-Q., Guo, T.-Y., 2007. Geological Map of the Tibetan Plateau and its Neighbouring Regions. Geological Publishing House, Beijing (in Chinese).

Kandiano, E.S., Bauch, H.A., Muller, A., 2004. Sea surface temperature variability in the North Atlantic during the last two glacial-interglacial cycles: comparison of faunal, oxygen isotopic, and $\mathrm{Mg} / \mathrm{Ca}$ - derived records. Palaeogeography Palaeoclimatology Palaeoecology 204, 145-164.

Kasper, T., Heaberzettl, S., Doberschütz, D., Daut, D., Wang, J.-B., Zhu, L.-P., Nowaczyk, N., Mäusbacher, R., 2012. Indian Ocean Summer Monsoon (IOSM) dynamics within the past $4 \mathrm{ka}$ recorded in the sediments of Lake Nam Co, Central Tibetan Plateau (China). Quaternary Science Reviews 39, 73-85.

Keeling, C.D., 1979. The Suess effect: ${ }^{13}$ Carbon- $-{ }^{14}$ Carbon interrelations. Environment International 2, 229-300.

Kehrwald, N.M., Thompson, L.G., Yao, T.D., Mosley-Thompson, E., Schotterer, U., Alfimov, V., Beer, J., Eikenberg, J., Davis, M.E., 2008. Mass loss on Himalayan glacier endangers water resources. Geophysical Research Letters 35. http:// dx.doi.org/10.1029/2008GL035556.

Kelts, K., Chen, K.-Z., Lister, G., Yu, J.-Q., Gao, Z.-H., Niessen, N., Bonani, G., 1989. Geological fingerprints of climate history: a cooperative study of Qinghai Lake, China. Eclogae Geologicae Helvetiae 82, 167-182.

Kramer, A., Herzschuh, U., Mischke, S., Zhang, C.-J., 2009. Late Quaternary environmental history of the south-eastern Tibetan Plateau inferred from the Lake Naleng non-pollen palynomorph record. Vegetation History and Archaeobotany. http://dx.doi.org/10.1007/s00334-00009-00219-00335.

Kramer, A., Herzschuh, U., Mischke, S., Zhang, C.-J., 2010. Late glacial vegetation and climate oscillations on the southeastern Tibetan Plateau inferred from the Lake Naleng pollen profile. Quaternary Research 73, 324-335.

Li, M.-H., Kang, S.-C., Zhu, L.-P., Zheng, M.-P., 2008. Late Holocene climatic and environmental changes inferred from multi-proxies from Zabuye Saline Lake in Tibet. Arid Land Geography 31, 333-340 (in Chinese with English Abstract).

Li, Y.-F., Zhang, Q.-S., Li, B.-Y., Gasse, F., 1994. Ostracod fauna and environmental changes during the past 17000 years in the western Tibet. Acta Geographica Sinica 49, 46-54 (in Chinese with English Abstract).

Liang, E.-Y., Shao, X.-M., Xu, Y., 2009. Tree-ring evidence of recent abnormal warming on the southeast Tibetan Plateau. Theoretical and Applied Climatology 98, 9-18. http://dx.doi.org/10.1007/s00704-00008-00085-00706.

Lin, X., Zhu, L.-P., Wang, Y., Wang, J.-B., Xie, M.-P., Ju, J.-T., Maüsbacher, R., Schwalb, A., 2008. Environmental changes reflected by n-alkanes of lake core in Nam Co on the Tibetan Plateau since 8.4 ka BP. Chinese Science Bulletin 53, 3051-3057 (in Chinese)

Lister, G.S., Kelts, K., Chen, K.-Z., Yu, J.-Q., Niessen, F., 1991. Lake Qinghai, China: closed-basin lake levels and the oxygen isotope record for ostracoda since the latest Pleistocene. Palaeogeography Palaeoclimatology Palaeoecology 84, $141-162$. 
Liu, J.-Y., Yuan, H.-R., Zheng, M.-P., Liu, X.-F., 2007. Micropaleontology, environmental and climatic changes of the Nyer Co paleolake in western Tibet between 20000-2000 a BP. Journal of Paleogeography 9, 575-587 (in Chinese with English Abstract).

Liu, X.-Q., Shen, J., Wang, S.-M., Wang, Y.-B., Liu, W.-G., 2006. Southwest monsoon changes indicated by oxygen isotope of ostracode shells from sediments in Qinghai Lake since the late Glacial. Chinese Science Bulletin 51, 2690-2694 (in Chinese).

Liu, X.-O., Dong, H.-L., Rech, J.A., Matsumoto, R., Yang, B., Wang, Y.-B., 2008. Evolution of Chaka Salt Lake in NW China in response to climatic change during the latest Pleistocene-Holocene. Quaternary Science Reviews 27, 867-879.

Liu, X.-Q., Dong, H.-L., Yang, X.-D., Herzschuh, U., Zhang, E.-L., Stuut, J.-W., Wang, Y.B., 2009. Late Holocene forcing of the Asian winter and summer monsoon as evidenced by proxy records from the northern Qinghai-Tibetan Plateau. Earth and Planetary Science Letters 280, 276-284.

Ma, R.-H., Yang, G.-S., Duan, H.-T., Jiang, J.-H., Wang, S.-M., Feng, X.-Z., Li, A.-N., Kong, F.-X., Xue, B., Wu, J.-L., Li, S.-J., 2011. China's lakes at present: number, area and spatial distribution. Science in China Series D 54, 283-289.

Meyers, P.A., 2003. Applications of organic geochemistry to paleolimnological reconstructions: a summary of examples from the Laurentian Great Lakes. Organic Geochemistry 34, 261-289.

Mischke, S., Zhang, C.-J., 2010. Holocene cold events on the Tibetan Plateau. Global and Planetary Change 72, 155-163.

Mischke, S., Herzschuh, U., Zhang, C.-J., Bloemendal, J., Riedel, F., 2005. A Late Quaternary lake record from the Qilian Mountains (NW China): lake level and salinity changes inferred from sediment properties and ostracod assemblages. Global and Planetary Change 46, 337-359.

Mischke, S., Kramer, M., Zhang, C.-J., Shang, H.-M., Herzschuh, U., Erzinger, J., 2008. Reduced early Holocene moisture availability in the Bayan Har Mountains, northeastern Tibetan Plateau, inferred from a multi-proxy lake record. Palaeogeography Palaeoclimatology Palaeoecology 267, 59-76.

Mischke, S., Zhang, C.-J., Börner, A., Herzschuh, U., 2009. Lateglacial and Holocene variation in aeolian sediment flux over the northeastern Tibetan Plateau recorded by laminated sediments of a saline meromictic lake. Journal of Quaternary Science 25, 162-177.

Mischke, S., Aichner, B., Diekmann, B., Herzschuh, U., Plessen, B., Wünnemann, B., Zhang, C.-J., 2010. Ostracods and stable isotopes of a late glacial and Holocene record from the NE Tibetan Plateau. Chemical Geology 276, 95-103.

Morrill, C., Overpeck, J.T., Cole, J.E., Liu, K.-B., Shen, C.-M., Tang, L.-Y., 2006. Holocene variations in the Asian monsoon inferred from the geochemistry of lake sediments in central Tibet. Quaternary Research 65, 232-243.

Paillard, D., 1998. The timing of Pleistocene glaciations from a simple multiple-state climate model. Nature 391, 378-381.

Paillard, D., Parrenin, D., 2004. The Antarctic ice-sheet and the triggering of deglaciations. Earth and Planetary Science Letters 227, 263-271.

Peng, J.-L., 1997. Ostracod assemblages and environmental changes during 13000-4500 a BP in Peiku Co, Tibet. Acta Micropalaeontologica Sinica 14, 239-254 (in Chinese with English Abstract).

Porter, S.C., An, Z.-S., 1995. Correlation between climate events in the North Atlantic and China during the last glaciations. Nature 375, 305-308.

Porter, S.C., 2001. Chinese loess record of monsoon climate during the last glacialinterglacial cycle. Earth Science Reviews 54, 115-128.

Qiu, J., 2008. China: the third pole. Nature 454, 393-396.

Sarkanten, K.V., Ludwig, C.H., 1971. Lignins: Occurrence, Formation, Structure and Reactions. Wiley-Interscience, New York

Schütt, B., Berking, J., Frechen, M., Frenzel, P., Schwalb, A., Wrozyna, C., 2010. Late Quaternary transition from lacustrine to a fluvio-lacustrine environment in the north-western Nam Co, Tibetan Plateau, China. Quaternary International 218, 104-117.

Scott, E.M., 2007. Radiocarbon dating - Sources of error. In: Elias, S.A. (Ed.), Encyclopedia of Quaternary Science. Elsevier, pp. 2918-2923.

Shao, X.-M., Wang, S.-Z., Xu, Y., Zhu, H.-F., Xu, X.-G., Xiao, Y.-M., 2007. A 3500 year master tree-ring dating chronology from the northeastern part of the Qaidam Basin. Quaternary Sciences 27, 477-485 (in Chinese with English Abstract).

Shao, X.-M., Wang, S.-Z., Zhu, H.-F., Xu, Y., Liang, E.-Y., Yin, Z.-Y., Xu, X.-G., Xiao, Y.-M., 2009. A 3585-year ring-width dating chronology of Qilian Juniper from the northeastern Qinghai-Tibetan Plateau. IAWA Journal 30, 379-394.

Shen, H.-Y., Li, S.-J., Yu, S.-B., Yao, S.-C., 2007. Grain-size characteristics of sediments from the Zigetang Co Lake, Tibetan Plateau and their environmental implication. Quaternary Sciences 27, 613-619 (in Chinese with English Abstract).

Shen, J., Liu, X.-Q., Wang, S.-M., Matsumoto, R., 2005. Palaeoclimatic changes in the Qinghai Lake area during the last 18,000 years. Quaternary International 136, 131-140.

Sheppard, P.R., Tarasov, P.E., Graumlich, L.J., Heussner, K.U., Wagner, M., Österle, H., Thompson, L.G., 2004. Annual precipitation since 515 BC reconstructed from living and fossil juniper growth of northeastern Qinghai Province, China. Climate Dynamics 23, 869-881.

Stein, M., Migowski, C., Bookman, R., Lazar, B., 2004. Temporal changes in radiocarbon reservoir age in the Dead Sea - Lake Lisan system. Radiocarbon 46, 649-655.

Strachey, H., 1853. Physical Geography of Western Tibet. Journal of the Royal Geographical Society of London 23, 1-69.

Stuiver, M., Reimer, P.J., Reimer, R., 2011. CALIB 6.1.1 (WWW Program and Documentation)
Tang, L.-Y., Shen, C.-M., Li, C.-H., Peng, J.-L., Liu, H., Liu, K.-B., Morrill, C., Overpeck, J.T., Cole, J.E., Yang, B., 2009. Pollen inferred vegetation and environmental changes on the central Tibetan Plateau since $8200 \mathrm{yr}$ BP. Science in China Series D 39, 615-625 (in Chinese).

Tang, L.-Y., Shen, C.-M., Liu, K.-B., Yu, S.-Y., Li, C.-H., 2004. Pollen inferred climate change in the southeast Tibet since Last Glacial Maximum. Science in China Series D 34, 436-442 (in Chinese).

Tans, P.P., de Jong, A.F.M., Mook, W.G., 1979. Natural atmospheric ${ }^{14} \mathrm{C}$ variation and the Suess effect. Nature 280, 826-828.

Thompson, L.G., Yao, T., Davis, M.E., Henderson, K.A., Mosley-Thompson, E., Lin, P.N., Beer, J., Synal, H.A., Cole-Dai, J., Bolzan, J.F., 1997. Tropical climate instability: the last Glacial cycle from a Qinghai-Tibetan ice core. Science 276, 1821-1825.

Thompson, L.G., Yao, T., Mosley-Thompson, E., Davis, M.E., Henderson, K.A., Lin, P.N., 2000. A high-resolution millennial record of the south Asian monsoon from Himalayan Ice Cores. Science 289, 1916-1919.

Thompson, L.G., Mosley-Thompson, E., Davis, D.E., Mashiotta, T.A., Henderson, K.A Lin, P.-N., Yao, T.-D., 2006a. Ice core evidence for asynchronous glaciation on the Tibetan Plateau. Quaternary International 154-155, 3-10.

Thompson, L.G., Yao, T.-D., Davis, D.E., Mosley-Thompson, E., Lin, P.-N. Mashiotta, T.A., Zagordonov, V.S., 2006b. Holocene climate variability archived in the Puruogangri ice cap from the central Tibetan Plateau. Annals of Glaciology 43, 61-69.

van Campo, E., Cour, P., Huang, C.-X., 1996. Holocene environmental changes in Bangong Co basin (western Tibet). Part 2: the pollen record. Palaeogeography Palaeoclimatology Palaeoecology 120, 49-63.

Vandenberghe, J., Renssen, H., Huissteden, K.V., Nugteren, G., Konert, M., Lu, H. Dodonov, A., Buylaert, J.P., 2006. Penetration of Atlantic westerly winds into Central and East Asia. Quaternary Science Reviews 25, 2380-2389.

Wang, N.-L., Thompson, L.G., Davis, D.E., Mosley-Thompson, E., Yao, T.-D., Pu, J.-C., 2003. Influence of variations in NAO and SO on air temperature over the northern Tibetan Plateau as recorded by $\mathrm{d}^{18} \mathrm{O}$ in the Malan ice core. Geophysical Research Letters 30, 2167-2170.

Wang, R.-L., Scarpitta, S.C., Zhang, S.-C., Zheng, M.-P., 2002. Later pleistocene/ Holocene climate conditions of Qinghai-Xizang Plateau (Tibet) based on carbon and oxygen stable isotopes of Zabuye Lake sediments. Earth and Planetary Science Letters 203, 461-477.

Wang, S.-M., Dou, H.-S., 1998. Lakes in China. Science Publisher, Beijing (in Chinese). Wang, Y.-B., Liu, X.-Q., Yang, X.-D., Zhang, E.-L., Matsumoto, R., 2008. A 4000-yea moisture evolution recorded by sediments of Lake Kusai in the Hoh Xil area northern Tibetan Plateau. Journal of Lake Sciences 20, 605-612 (in Chinese with English Abstract).

Wang, Y., Shen, J., Wu, J.-L., Liu, X.-Q., Zhang, E.-L., Liu, E.-F., 2007. Hard-water effect correction of lacustrine sediment ages using the relationship between ${ }^{14} \mathrm{C}$ levels in lake waters and in the atmosphere: the case of Lake Qinghai. Journal of Lake Sciences 19, 504-508 (in Chinese with English Abstract).

Wang, Y., Shen, J., Xu, X.-N., Liu, X.-Q., Sirocko, F., Zhang, E.-L., Ji, J.-F., 2011. Environmental changes during the past 13500 cal. a BP deduced from lacustrine sediment records of Lake Qinghai, China. Chinese Journal of Geochemistry 30 479-489.

Watanabe, T., Matsunaka, T., Nakamura, T., Nishimura, M., Izutsu, Y., Minami, M. Watanabe Nara, F., Kakegawa, T., Wang, J.-B., Zhu, L.-P., 2010a. Last glacial-Holocene geochronology of sediment cores from a high-altitude Tibetan lake based on AMS ${ }^{14} \mathrm{C}$ dating of plant fossils: implications for palaeoenvironmental reconstructions. Chemical Geology 277, 21-29.

Watanabe, T., Matsunaka, T., Nakamura, T., Nishimura, M., Watanabe Nara, F, Kakegawa, T., Zhu, L.-P., 2010b. Changes of organic matter sources in sediment cores from a high-altitude lake (Pumoyum Co, southeastern Tibetan Plateau) over the last 19000 years. Nuclear Instruments and Methods in Physics Research B 268, 1070-1072.

Wei, K.-Q., Gasse, F., 1999. Oxygen isotopes in lacustrine carbonates of west China revisited: implications for post glacial changes in summer monsoon circulation. Quaternary Science Reviews 18, 1315-1334.

Wu, Y.-H., Lücke, A., Z-D, J., Wang, S.-M., Schleser, G.H., Battarbee, R.W., Xia, W.-L., 2006. Holocene climate development on the central Tibetan Plateau: a sedimentary record from Cuoe Lake. Palaeogeography Palaeoclimatology Palaeoecology 234, 328-340.

Wu, Y.-H., Lücke, A., Wunnemann, B., Li, S.-J., Wang, S.-M., 2007. Holocene climate change in the central Tibetan Plateau inferred by lacustrine sediment geochemical records. Science in China Series D 37, 1185-1191 (in Chinese).

Wu, Y.-H., Li, S.-J., Lücke, A., Wünnemann, B., Zhu, L.-P., Reimer, P., Wang, S.-M., 2010. Lacustrine radiocarbon reservoir ages in Co Ngoin and Zige Tangco, central Tibetan Plateau. Quaternary International 212, 21-25.

Xie, M.-P., Zhu, L.-P., Peng, P., Zhen, X.-L., Wang, Y., Ju, J.-T., Schwalb, A., 2008. Ostracodes assemblages and their environmental significance from lake core of Nam Co, Tibetan Plateau. Acta Geographica Sinica 63, 931-944 (in Chinese with English Abstract)

Yang, X.-P., Scuderi, L.A., 2010. Hydrological and climatic changes in deserts of China since the late Pleistocene. Quaternary Research 73, 1-9.

Yang, X.-P., Ma, N.-N., Dong, J.-F., Zhu, B.-Q., Xu, B., Ma, Z.-B., Liu, J.-Q., 2010 Recharge to the inter-dune lakes and Holocene climate changes in the Badain Jaran Desert, western China. Quaternary Research 73, 10-19.

Yang, X.-P., Scuderi, L.A., Paillou, P., Liu, Z.-T., Li, H.-W., Ren, X.-Z., 2011. Quaternary environmental changes in the drylands of China - A critical Review. Quaternary Science Reviews 30, 3219-3233. 
Yao, T.-D., Shi, Y.-F., Thompson, L.G., 1992. The Holocene climatic changes in Mt. Qilian as recorded in Dunde ice core. In: Shi, Y.-F., Kong, Z.-C. (Eds.), The Climate and Environment in China during the Holocene Megathermal. Ocean Press, Beijing, pp. 206-211.

Yao, T.-D., Thompson, L.G., Mosley-Thompson, E., Yang, Z.-H., 1996. Climatological significance of $\delta^{18} \mathrm{O}$ in north Tibetan ice cores. Journal of Geophysical Research 101, 29531-29537.

Yao, T.-D., Shi, Y.-F., Thompson, L.G., 1997. High resolution record of paleoclimate since the Little Ice Age from the Tibetan ice cores. Quaternary International 37, 19-23.

Yao, T.-D., 1999. Abrupt climatic variations on the Qinghai-Tibetan Plateau during the Last Ice Age a comparative study of the Guliya ice core with the GRIP ice core. Science in China Series D 42, 358-368.

Yao, T.-D., Li, Z.-X., Thompson, L.G., Mosley-Thompson, E., Wang, Y.-Q., Tian, L.-D., Wang, N.-L., Duan, K.-Q., 2006. $\delta^{18} \mathrm{O}$ records from Tibetan ice cores revealed differences in climatic changes. Annals of Glaciology 43, 1-7.

Yao, T.-D., 2008. Map of Glaciers and Lakes on the Tibetan Plateau and Adjoining Regions. Xi'an Cartographic Publishing House, Xi'an.

Yu, J.-Q., Kelts, K., 2002. Climatic change in the northeast Qinghai-Tibet Plateau during the late glacial/Holocene transition. Quaternary Sciences 22, 413-423 (in Chinese with English Abstract)

Yu, J.-Q., Zhang, L.-S., 2008. Lake Qinghai: Paleoenvironment and Paleoclimate. Science Press, Beijing.

Yu, S.-Y., Shen, J., Coleman, S.M., 2007. Modeling the radiocarbon reservoir effect in lacustrine systems. Radiocarbon 49, 1241-1254.
Zhang, C.-J., Mischke, S., 2009. A Lateglacial and Holocene lake record from the Nianbaoyeze Mountains and inferences of lake, glacier and climate evolution on the eastern Tibetan Plateau. Quaternary Science Reviews 28, 1970-1983.

Zhang, P.-X., Zhang, P.-Z., Qian, G.-M., Li, H.-J., Xu, L.-M., 1994. The study of paleoclimatic parameter of Qinghai Lake since Holocene. Quaternary Sciences 14, 225-228 (in Chinese and English abstract).

Zhao, Y., Yu, Z.-C., Chen, F.-H., Ito, E., Zhao, C., 2007a. Holocene vegetation and climate history at Hurleg Lake in Qaidam Basin, northwest China. Review of Palaeobotany and Palynology 145, 275-288.

Zhao, Z.-M., Liu, A.-M., Peng, W., Ji, W.-H., Li, R.-S., Wang, Y.-Z., Zhu, Y.-T., 2007b. Holocene environmental changes of northern Qinghai-Tibetan Plateau based on spore-pollen analysis. Arid Land Geography 30, 381-391 (in Chinese with English Abstract).

Zheng, M.-P., Yuan, H.-R., Liu, J.-Y., Li, Y.-H., Ma, Z.-B., Sun, Q., 2007. Sedimentary characteristics and paleoenvironmental records of Zabuye Salt Lake, Tibetan Plateau, since 128 ka BP. Acta Geologica Sinica 81, 1608-1617 (in Chinese with English Abstract).

Zhou, A.-F., Chen, F.-H., Wang, Z.-L., Yang, M.-L., Qiang, M.-R., Zhang, J.-W., 2009. Temporal change of radiocarbon reservoir effect in Sugan Lake, northwestern China during the lake Holocene. Radiocarbon 51, 529-535.

Zhu, L.-P., Wu, Y.-H., Wang, J.-B., Lin, X., Ju, J.-T., Xie, M.-P., Li, M.-H., Mäusbacher, R., Schwalb, A., Daut, G., 2008. Environmental changes since 8.4 ka reflected in the lacustrine core sediments from Nam Co, central Tibetan Plateau. The Holocene 18, 831-839. 